\title{
Latest Pliocene to recent thick-skinned tectonics at the Upper Rhine Graben - Jura Mountains junction
}

\author{
KAMIL UstasZEWSKi ${ }^{1} \&$ STEFAn M. Schmid
}

Keywords: Neotectonics, Upper Rhine Graben, Jura Mountains, Permo-Carboniferous trough, Rhine-Bresse Transfer Zone, 1356 Basel earthquake

\begin{abstract}
The southernmost Upper Rhine Graben and adjacent Jura experienced basement-rooted shortening that occurred after the deposition of the Pliocene fluvial "Sundgau gravels". Folds affecting the base of these gravels systematically trend NE to ENE. Combined evidence from reflection seismic lines and contour maps of the base-Tertiary and base-Pliocene levels indicates that these folds probably formed by thick-skinned reactivation of both NNE-SSW and WSW-ENE-striking faults. This thick-skinned shortening is NW-SE oriented, i.e. parallel to the maximum horizontal stresses inferred from seismotectonics. NNE-SSW-striking faults (paralleling the Upper Rhine Graben) have been reactivated in sinistral strike-slip mode. However, dextrally transpressive reactivation of the WSW-ENE-trending faults that belong to the Rhine-Bresse Transfer Zone is interpreted to predominate.

Deflections of recent river courses around the crests of en-échelon-aligned surface anticlines suggest that the deformation is ongoing at present.
\end{abstract}

Retro-deformation of the folds affecting the base of the Sundgau gravels indicates horizontal displacement rates of about $0.05 \mathrm{~mm} / \mathrm{a}$. This corresponds to a minimum strain rate in the order of $2 \cdot 10^{-16} \mathrm{~s}^{-1}$, given the maximum time span of 2.9 Ma for this deformation, i.e. the biostratigraphically determined minimum age of the gravels. A change from thin-skinned tectonics, that prevailed during the main phase of Jura folding, to very probably still ongoing thick-skinned tectonics is inferred to have occurred in the Late Pliocene. We speculate that this change might be linked to the incipient inversion of Permo-Carboniferous troughs within the Alpine foreland in general. This inversion in dextrally transpressive or purely compressive mode along a WNW-ESE-trending basement fault, that is part of the Rhine-Bresse Transfer Zone, which in turn was prestructured during the formation of the Permo-Carboniferous troughs, could have triggered the 1356 Basel earthquake.

\section{Introduction}

\subsection{Research objectives}

The present day architecture of the northwestern Alpine foreland largely resulted from the interplay between extensional and collisional tectonics that took place since early Cenozoic times. The resulting interference is particularly complex, where the Eo- to Oligocene southern Upper Rhine Graben (URG) abuts the northern margin of the Mio- to Pliocene fold and thrust belt of the Jura Mountains. The latter formed as a consequence of Alpine subduction and collision.

According to the widely accepted concept of thin-skinned Jura folding, which postulates décollement via complete decoupling between basement and cover along Triassic evaporites (e.g. Buxtorf 1907; Laubscher 1961; Burkhard 1990; Jordan 1992), the role of pre-existing basement faults linked to the formation of the URG would only be a passive one during later compressive events. Such pre-existing faults would merely act as nuclei during the formation of Jura-type folds, thrusts and transverse strike-slip structures such as oblique ramps. However, a minority of authors prefers a thick-skinned origin of all, or at least of parts, of the shortening in the Jura Mountains and adjacent areas. Thereby pre-existing basement faults would play an active role. They could, for example, be reactivated in terms of strike-slip faulting within a basement that is decoupled from folding of the sedimentary cover above the Triassic detachment horizon (Pavoni 1961), or alternatively, by the inversion of faults delimiting the Permo-Carboniferous troughs of the northwestern foreland of the Alps (e.g. Pfiffner et al. 1997).

Controversies addressing the thick-skinned vs. thinskinned dilemma often overlook the evolution in time and

Geologisch-Paläontologisches Institut, Universität Basel, Bernoullistrasse 32, CH-4056 Basel, Switzerland.

1 Corresponding author: K. Ustaszewski. E-mail: Kamil.Ustaszewski@unibas.ch 


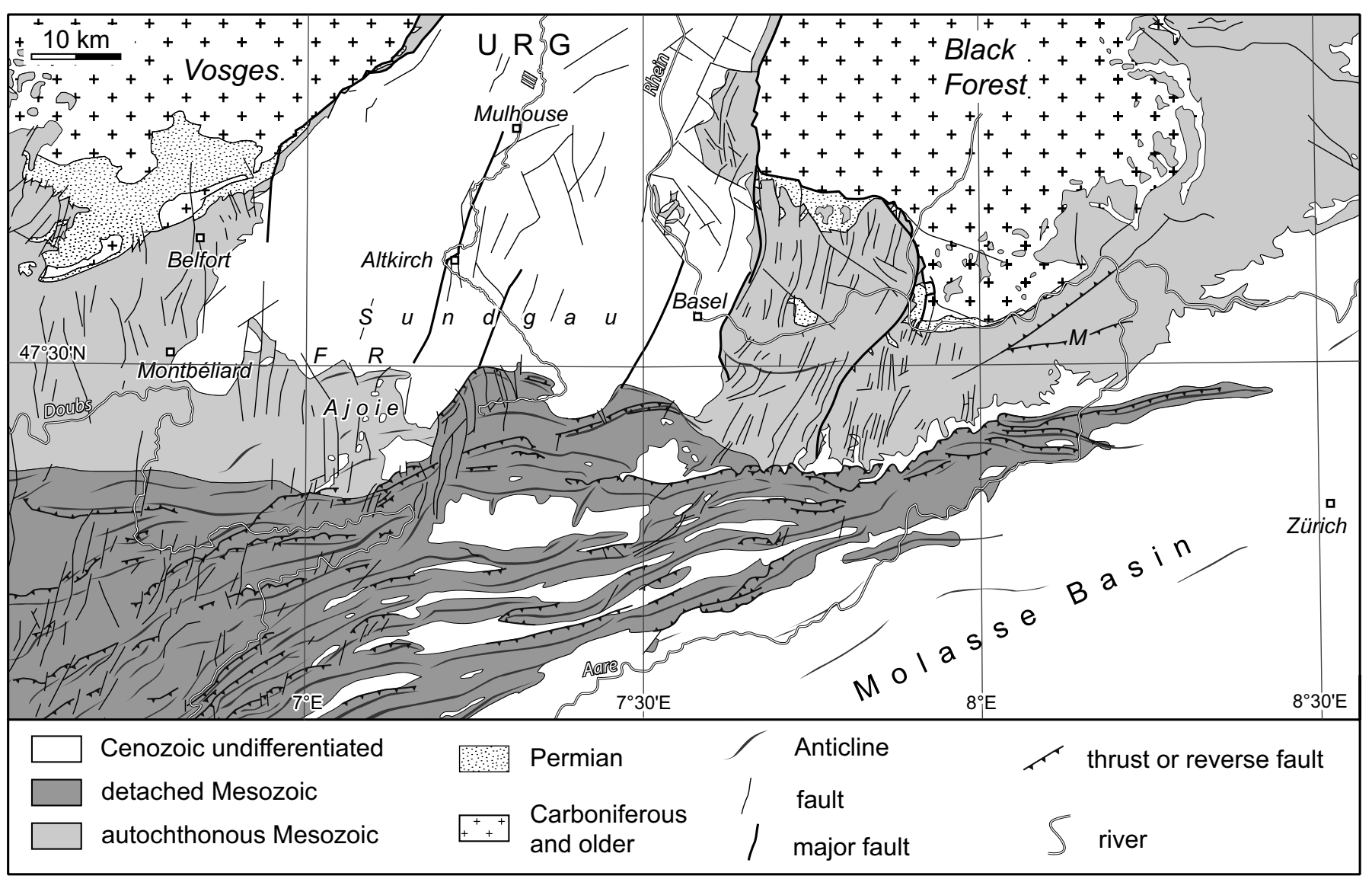

Fig. 1. Tectonic map of the study area. Geographic names are in italics. $\mathrm{F}=$ Florimont anticline, $\mathrm{R}=$ Réchésy anticline, $\mathrm{M}=\mathrm{Mandach}$ thrust.

space of post-Oligocene shortening in the northwestern Alpine foreland. Evidence for a thin-skinned origin of the main structural features within the Jura fold-and-thrust belt, which essentially formed within a relatively short time span between the Late Miocene and Early Pliocene, is overwhelming and perfectly feasible from both mechanical and geometrical viewpoints (e.g. Laubscher 1961; Müller \& Briegel 1980; Burkhard 1990; Jordan 1992; Sommaruga 1997; Burkhard \& Sommaruga 1998). This view can easily be reconciled with thick-skinned reactivation of pre-existing basement faults in latest Pliocene to recent times, i.e. during a late stage or after the formation of the thin-skinned Jura belt, a postulate which is by now supported by abundant evidence (e.g. Becker 2000; Giamboni et al. 2004a,b; Ustaszewski et al 2005a; Ustaszewski \& Schmid 2006).

At present, the southern end of the URG is characterised by increased seismicity, as seen in the clustering of seismic events in both the historical and the instrumental earthquake catalogues of Switzerland (Swiss Seismological Service 2003). Earthquakes, for instance, have repeatedly harmed the city of Basel in medieval times. The most severe earthquake occurred in $1356 \mathrm{AD}$ with an estimated epicentral intensity between IX and X (Mayer-Rosa \& Cadiot 1979). The inferred focal depth of this earthquake is at a mid-crustal level, and most other earthquakes in the northwestern Alpine foreland span the entire crustal column down to the base of the upper crust (Deichmann et al. 2000a). This suggests basement reactivation and, hence, a thick-skinned scenario at least for the seismogenic components of neotectonic activity.

However, despite dedicated research (Meyer et al. 1994; Nivière \& Winter 2000; Meghraoui et al. 2001; Ferry et al. 2005; Lambert et al. 2005) the seismic source of the $1356 \mathrm{AD}$ Basel earthquake (strike slip, thrust/reverse or normal fault?) has not yet been unambiguously identified. Also, there is no general agreement yet, whether the currently ongoing deformation in the northwestern Alpine foreland still predominantly affects the sedimentary cover (ongoing thin-skinned tectonics, deep-seated seismogenic activity being of minor importance) or whether basement and cover currently deform by the same amounts (thick-skinned tectonics). Solving such questions is of key importance for seismic hazard assessment studies, issues that require an accurate knowledge of present-day rates of deformation and fault kinematics.

This study contributes to the above-mentioned debates by 


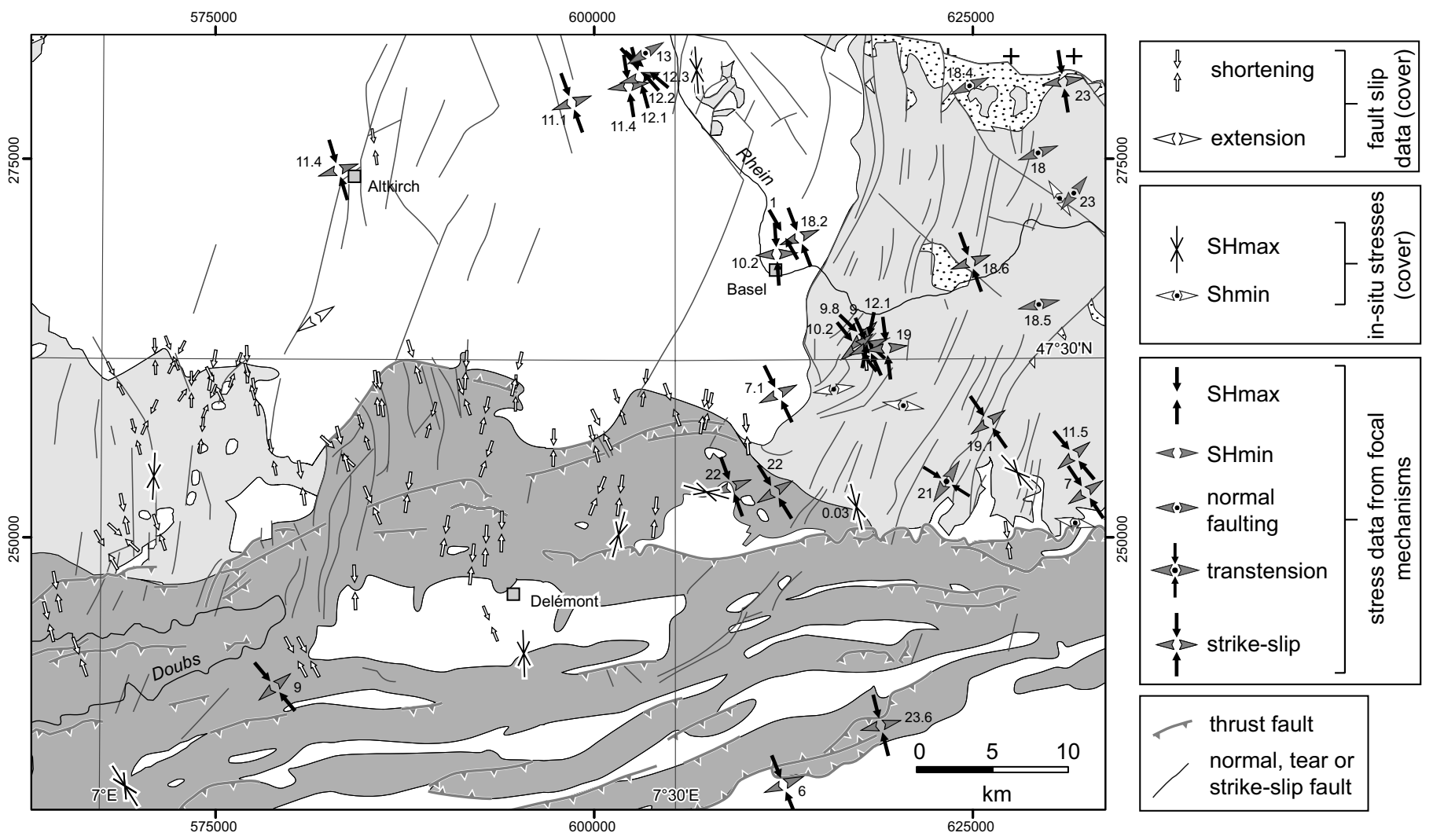

Fig. 2. Comparison of "paleostress" data derived from the analysis of fault-slip data (see Ustaszewski \& Schmid 2006) and recent stress data in the SE corner of the Upper Rhine Graben taken from the 2003 release of the World Stress Map project (Reinecker et al. 2003). The near-surface recent stress data stem from various methods of in-situ stress measurements in the sedimentary cover. The depth of deep-seated seismic events, taken from the inversion of seismotectonic dislocations, is indicated in $\mathrm{km}$. Note that SHmax-orientations regarding recent near-surface deformation tend to scatter between NNW and NNE, paralleling the shortening directions determined from the fault-slip data, particularly those measured in the detached Mesozoic and in the autochthonous Mesozoic in the Ajoie. SHmax-orientations obtained from seismotectonic activity within the crystalline basement, including Late Paleozoic sediments, however, are predominantly and more systematically NW-SE-oriented. Patterns are as in Fig. 1. Anticline crests are omitted for reasons of legibility. Numbers on map margin refer to Swiss National coordinates.

combining new results and literature data regarding: (1) geomorphologic observations, (2) kinematic data from fault-slip analysis and (3) evidence from reflection seismic lines and newly compiled subsurface maps. The data presented in this study favour the interpretation that basement-rooted (i.e. thick-skinned) tectonics are dominant since the latest Pliocene, whereas Jura-type décollement (i.e. thin-skinned) tectonics ceased at about that time. The stress field evolution in the sedimentary cover is discussed by comparing "paleostresses" (derived from the analysis of fault-slip data; Ustaszewski \& Schmid 2006) and recent stresses. Furthermore, it is discussed whether the observed neotectonic structures could be related to an incipient (and potentially seismogenic) inversion of Permo-Carboniferous troughs in the subsurface.

\subsection{Geological setting and previous work}

The study area is located in northwestern Switzerland and adjacent France, at the junction of the southernmost URG and the northern Jura fold and thrust belt (Fig. 1). In the following, we focus only on the regional aspects that are indispensable for understanding the neotectonic setting. More exhaustive descriptions of the regional geology are found in Becker (2000), Giamboni et al. (2004a), Dèzes et al. (2004) and Ustaszewski \& Schmid (2006). The usage of the term "neotectonic" in this study refers to tectonic processes that occurred since the Late Pliocene.

Among the earliest studies addressing neotectonics in the area were those of Liniger $(1963,1964)$, who described in great detail a gentle E-W-trending anticline at the junction between the Tabular Jura and the URG in the Ajoie (Réchésy Anticline, Fig. 1). Based on the observation that the gentle anticline affects a sheet of Pliocene gravels (so-called "Sundgau gravels", see below), he inferred a largely postPliocene age of folding which he considered to have occurred at a late stage during thin-skinned Jura deformation. Théobald et al. (1977) tentatively portrayed a number of anticlines at the southern end of the URG and further west into 


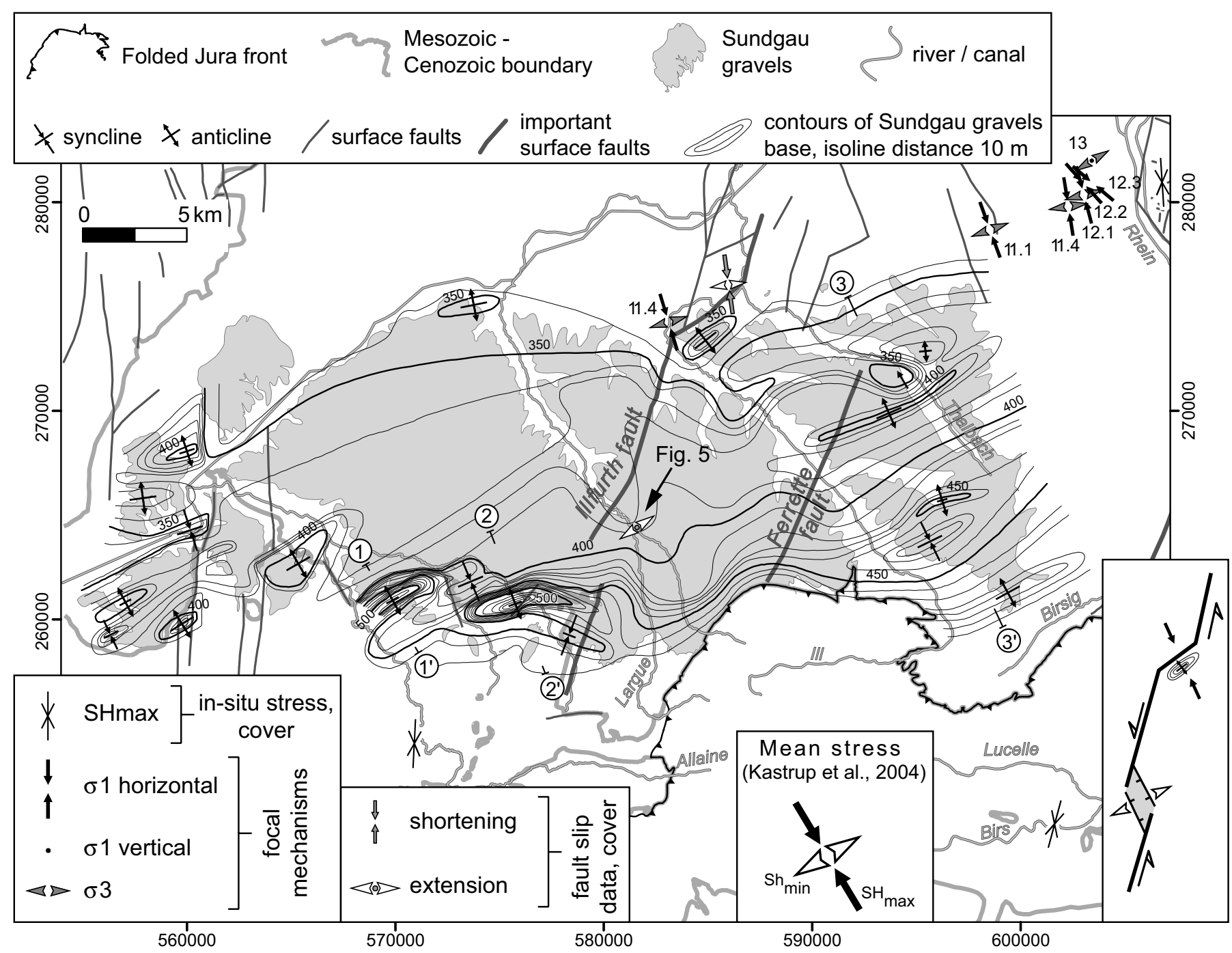

Fig. 3. Contour map of the base of the Pliocene Sundgau gravels in metres above sea level (after Giamboni et al. 2004a). Data on the recent stress field comprise in-situ stress measurements and earthquake focal mechanisms, extracted from the World Stress Map project 2003 release (Reinecker et al. 2003). The numbers next to the stress symbols indicate the depth of the events in km. The traces of the cross sections 1 to 3 (Fig. 4) are indicated. The clustered events in the NE corner correspond to the Sierentz 1980 earthquake swarm. Bottom right inset: kinematic sketch of the Illfurth fault explaining the occurrence of restraining and releasing bends.

the Doubs and Ognon valleys, to which they also assigned a post-Pliocene age.

Giamboni et al. (2004a) resumed and expanded the observations of Liniger $(1963,1964)$ onto a larger area. They identified two E-W-trending, en-échelon aligned surface anticlines of Post-Pliocene age (Florimont and Réchésy anticlines, Fig. 1) at the URG-Tabular Jura junction. Based on interpretations of reflection seismic lines, they attributed the formation of these folds to dextral reactivation of an ENE-WSW-trending pre-existing basement fault system within the Pre-Mesozoic basement (see figs. $5 \& 7$ in Giamboni et al. 2004a). Such faults are widely recognised in the area and belong to a set of faults bounding the ENE-WSW-trending Permo-Carboniferous trough system. This trough system extends eastwards into the
Northern Swiss Permo-Carboniferous trough (Diebold 1988; Diebold \& Naef 1990; Diebold et al. 1991; Müller et al. 2002), also referred to as Constance-Frick trough (Diebold \& Noack 1997; Laubscher \& Noack 1997). This Late Paleozoic trough system is commonly held responsible for nucleating a Paleogene-age continental transfer zone between the URG in the $\mathrm{NE}$ and the Bresse Graben in the SW. This so-called Rhine Bresse Transfer Zone linked the simultaneous opening of the two graben systems by sinistral transtensive reactivation of ENE-oriented basement faults of the pre-existing Permo-Carboniferous trough system (Laubscher 1972, 1973; Bergerat \& Chorowicz 1981; Illies 1981; Ziegler 1992; Lacombe et al. 1993; Ustaszewski et al. 2005a,b). 

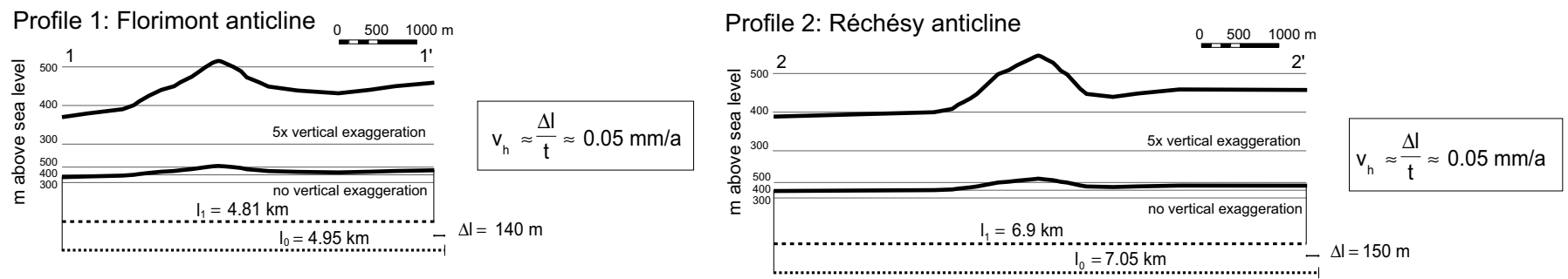

Profile 3: III valley

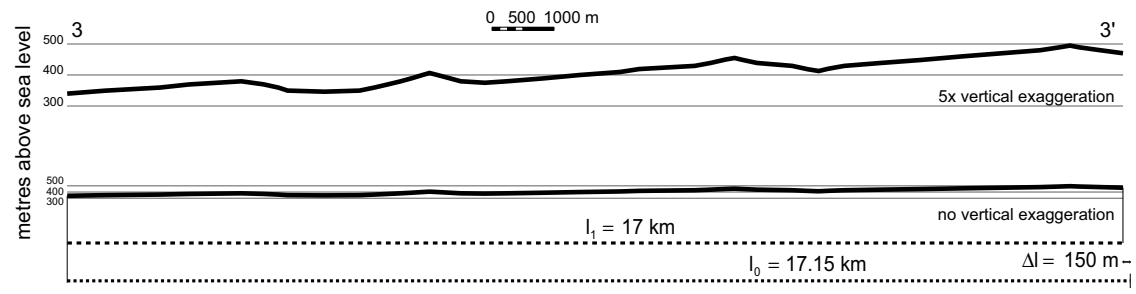

$\mathrm{v}_{\mathrm{h}} \approx \frac{\Delta \mathrm{l}}{\mathrm{t}} \approx 0.05 \mathrm{~mm} / \mathrm{a}$

Fig. 4. Three cross sections through the folded base of the Sundgau gravels, amounts of shortening and derived horizontal displacement rates by assuming that shortening started after deposition of the gravels (minimum age 2.9 Ma) and continued up to recent times. See Fig. 3 for location of the sections.

\subsection{Seismicity and recent displacement rates}

The orientation of maximum horizontal stresses (SHmax) in the northwestern Alpine foreland, inferred from fault plane solutions for seismic events and the inversion of focal mechanisms, is consistently NW-oriented (Plenefisch \& Bonjer 1997; Deichmann et al. 2000a; Reinecker et al. 2003; Kastrup et al. 2004; Fig. 2). Down to a depth of about $15 \mathrm{~km}$, there is a predominance of fault plane solutions indicating strike-slip, whereas from $15 \mathrm{~km}$ down to the MOHO normal faulting events prevail (Plenefisch \& Bonjer 1997; Deichmann et al. 2000a). The extension axes show a very stable NE-SW-orientation throughout.

However, the SHmax-orientations in the sedimentary cover, which is decoupled from the basement (comprising the crystalline basement, Permo-Carboniferous and Lower Triassic) along rheologically weak Middle and Upper Triassic evaporite layers, scatter from NNW over $\mathrm{N}$ to NNE, as is primarily deduced from in-situ stress measurements (Baumann 1981; Müller et al. 1987; Becker 1999, 2000; Reinecker et al. 2003; Fig. 2). The depth-dependent change in the orientation of SHmax is particularly well documented in boreholes along the easternmost Folded Jura (Müller et al. 1987, 2002). This decoupling has been used as an argument for still ongoing décollement tectonics. However, stress decoupling between basement and cover does not necessarily imply ongoing thinskinned tectonics, a postulate, which contrasts with recent work providing arguments for currently ongoing thick-skinned reactivation of basement faults (Meyer et al. 1994; Lopes Cardozo \& Granet 2003; Giamboni et al. 2004a; Ustaszewski et al. 2005a).
A recent compilation of GPS-data from 53 permanent stations from 4 different networks in Western Europe, with observation periods of up to 7 years between 1996 and 2003, allowed a determination of horizontal displacement rates relative to Eurasia. Stations located between $4^{\circ}$ and $16^{\circ} \mathrm{E}$, comprising the domain of the Alps and the northern Alpine foreland, show horizontal displacement rates between 0.1 and $2.9 \mathrm{~mm} / \mathrm{a}$ relative to Eurasia (Tesauro et al. 2005, their fig. 2). Convergence rates concerning the Swiss part of the northwestern Alpine foreland are in the order of less than $1 \mathrm{~mm} / \mathrm{a}$ (Müller et al. 2002). However, it is uncertain as to how much of the present-day convergence deduced for the earth's surface is accommodated by seismogenic activity within the directly underlying basement.

\section{Geomorphologic and geological field evidence for latest Pliocene to recent tectonics}

Pliocene fluvial gravels, cropping out in the southernmost URG and the adjacent Jura Mountains, play a key role in deciphering neotectonic (Late Pliocene to recent) activity. These so-called Sundgau gravels unconformably overlie both the Paleogene syn-rift sediments in the URG and the autochthonous Mesozoic in the Tabular Jura of the Ajoie (Fig. 3). The Sundgau gravels were deposited by a braided river, which flowed westward through southernmost Alsace ("Sundgau") towards the Bresse Graben (Théobald 1934; Manz 1936; Liniger 1966). The Sundgau gravels accumulated in a time span from 4.2 to $2.9 \mathrm{Ma}$, as determined biostratigraphically (Petit et al. 1996; Fejfar et al. 1998). During this 

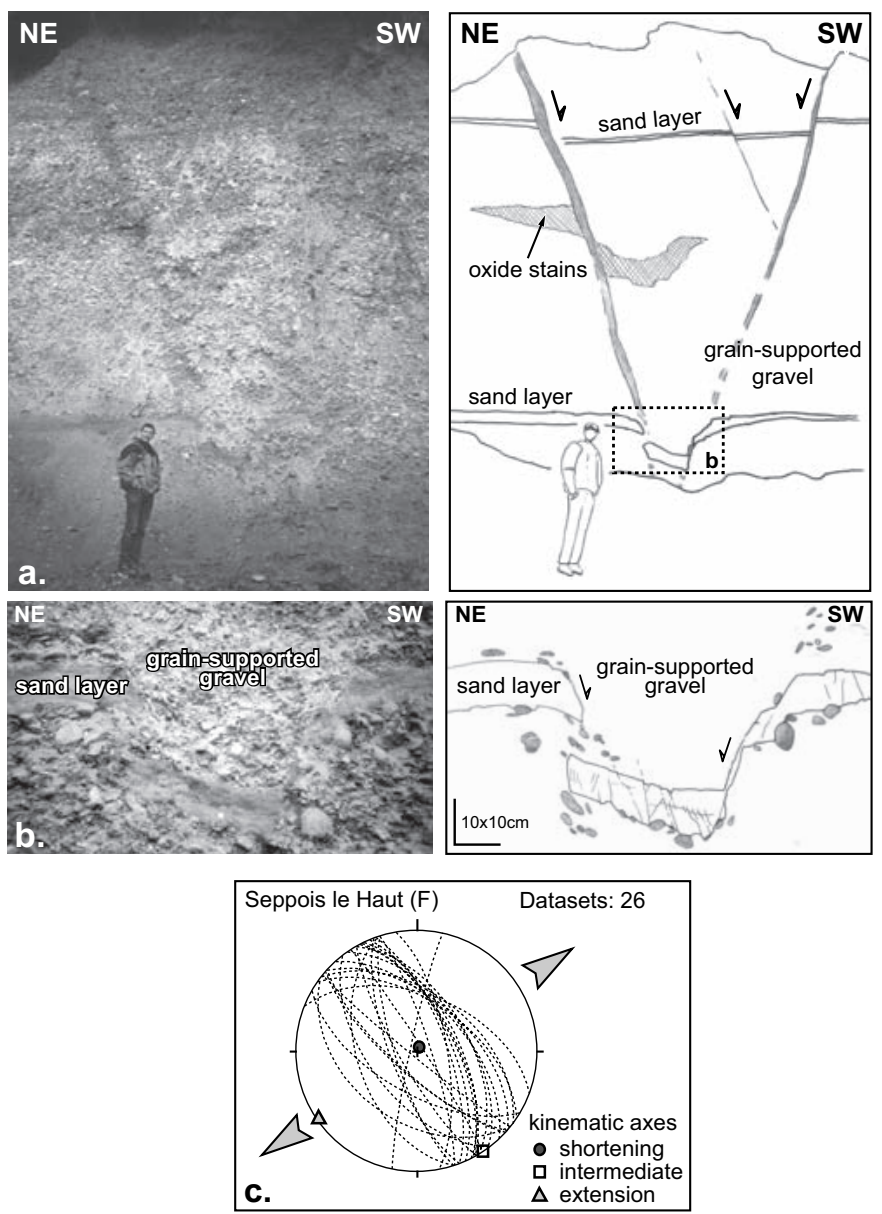

Fig. 5. Deformation features in the Sundgau gravels related to local extension near a releasing bend of strike slip faulting. (a) Conjugate normal faults affecting the Late Pliocene Sundgau gravels in an abandoned gravel pit in the Largue valley at Seppois le Haut, France (Swiss coordinates: $X=581 ' 600$, $\mathrm{Y}=264^{\prime} 400$ ). Intercalated sand lenses in the grain-supported gravels and oxide stains serve as markers. See Fig. 3 for location. (b) Sand layer affected by cmto $\mathrm{dm}$-scale conjugate normal faults. Outside the faulted sand layer the shear zone is traceable by rotated and broken pebbles. (c) Representation of faultorientations and of the shortening and extension axes in a lower hemisphere equal area projection.

time interval the drainage divide between the North Sea and the Mediterranean Sea was located around the Kaiserstuhl volcano, approximately $60 \mathrm{~km} \mathrm{~N}$ of the area investigated (e.g. Giamboni et al. 2004a, their fig. 4b). This riverbed was abandoned 2.9 Ma ago, associated with a southward shift of the drainage divide into the western Sundgau. Subsequently, the contiguous gravel cover was dissected by four N- to NWwards draining tributaries of the Doubs (Allaine) and Rhine (from W to E: Largue, Ill and Thalbach) rivers. These tributaries incised into the Paleogene syn-rift fill of the URG, thus exposing the base of the gravel sheet (Fig. 3). The eastern end of the Sundgau gravel sheet W of Basel is clearly erosional. Previous authors attributed the southward shift of the water divide either to a slow-down (or end) of upwarping of the Vosges-Black Forest arch (Dèzes et al. 2004), or alternatively, to accelerated subsidence in the northern URG and a concomitant drop of the local base level, causing subsequent regressive erosion in the southern URG (Doebl 1970; Schumacher 2002; Giamboni et al. 2004b). Our own data (Ustaszewski \& Schmid 2006 and this work) hint towards a third possible explanation, namely that both abandonment of the Sundgau riverbed and subsequent reorganisation of the drainage system were triggered by shortening-induced neotectonic uplift.

The thickness of the Sundgau gravels (Théobald et al. 1958; Liniger 1970a, 1970b; Ruhland et al. 1973) varies between 5 and $20 \mathrm{~m}$. These predominantly clast-supported, crudely bedded gravel beds were deposited in a shifting network of shallow, low-sinuosity channels. Intercalations of sand lenses are very rare. These sedimentological criteria suggest that deposition occurred on a nearly planar surface; hence this surface can be used as a reference plane for deciphering subsequent vertical tectonic movements. The contours of the base of the Sundgau gravels show a general increase in elevation from c. $350 \mathrm{~m}$ in the $\mathrm{N}$ to more than $450 \mathrm{~m}$ in the $\mathrm{S}$ (Théobald 1934; Giamboni et al. 2004a). Moreover, the contours reveal an array of syn- and anticlines with average amplitudes of 30-50 $\mathrm{m}$ and maximum amplitudes of up to $150 \mathrm{~m}$ regarding the two en-échelon anticlines in the southwest. These amplitudes exceed the thickness of the gravel sheet by about an order of magnitude. Hence it can be excluded that the contoured folds merely reflect the infilling of a pre-existing topography. Rather they testify to post-2.9 Ma horizontal shortening and related vertical uplift in the southernmost URG (Giamboni et al. 2004a).

Fig. 3 also compares the contours of the base of the Sundgau gravels with the available recent stress orientations for this particular area. The recent stresses, taken from the World Stress Map project (Reinecker et al. 2003), are again those inferred from earthquake focal mechanisms and in-situ stress measurements. The mean stress regime reveals strikeslip characteristics with a maximum horizontal stress (SHmax) oriented at around azimuth $330^{\circ}$ (Kastrup et al. 2004). Note that the fold trains in the Sundgau gravels trend largely perpendicular to present-day SHmax.

\subsection{Estimating displacement rates}

In order to quantify the amount of post-2.9 Ma horizontal shortening recorded by the Sundgau gravels, three cross-sections through their gently folded base, oriented perpendicular to the contour lines, were compiled and restored (Fig. 4). Profiles 1 and 2 traverse the two prominent Florimont and Réchésy anticlines (Fig. 1); cross-section 3 runs east of the Ill Valley and across several ENE-trending syn- and anticlines (Fig. 3). The amount of shortening varies between $1 \%$ (crosssection 3 ) and $2.8 \%$ (cross-section 1) across the 3 transects. Assuming this shortening to have commenced earliest at around 

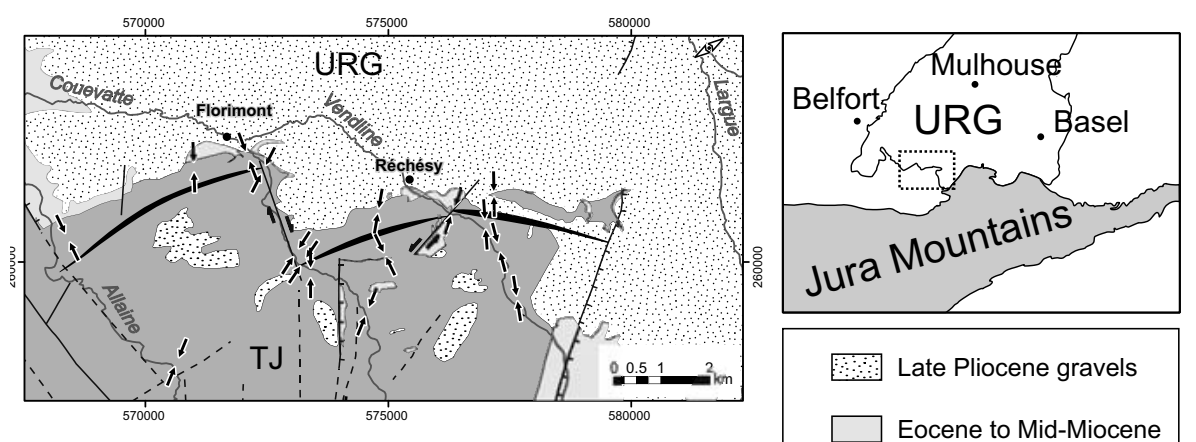

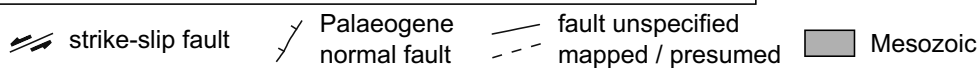

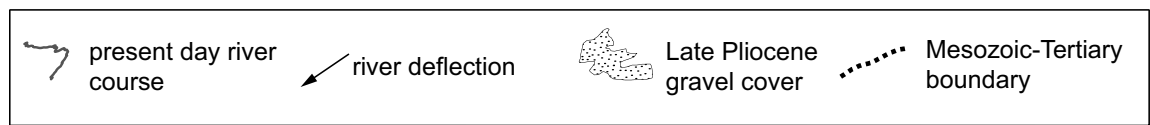
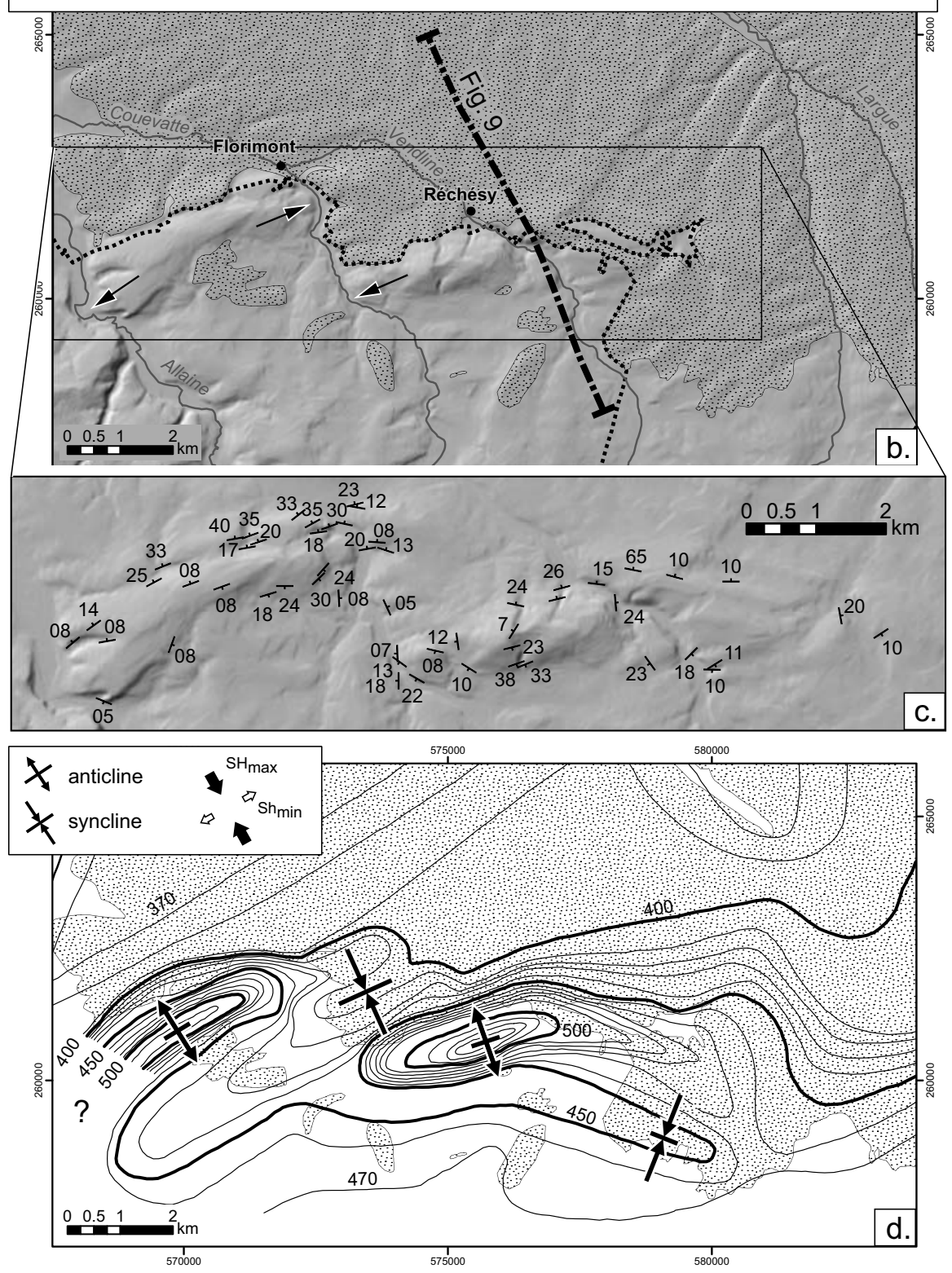

Fig. 6. The Florimont and Réchésy anticlines in northern Ajoie (a) Simplified geological map of the area around the en-échelon aligned anticlines at the Tabular Jura - URG boundary. Shortening (converging black arrows) and extension directions (diverging white arrows) from fault-slip data are shown (from Ustaszewski \& Schmid, 2006). (b) Shaded relief map illustrating the juvenile morphology of the two anticlines. Note the deflection of the Allaine and Coeuvatte rivers around the fold hinges. Reproduced by permission of swisstopo (BA068200). (c) Strike and dip of bedding planes measured in Mesozoic and Palaeogene sediments around the anticlines. (d) Contoured base of the Sundgau gravels (from Giamboni et al. 2004a). Bottom center inset: recent stress field after Kastrup et al. (2004). 


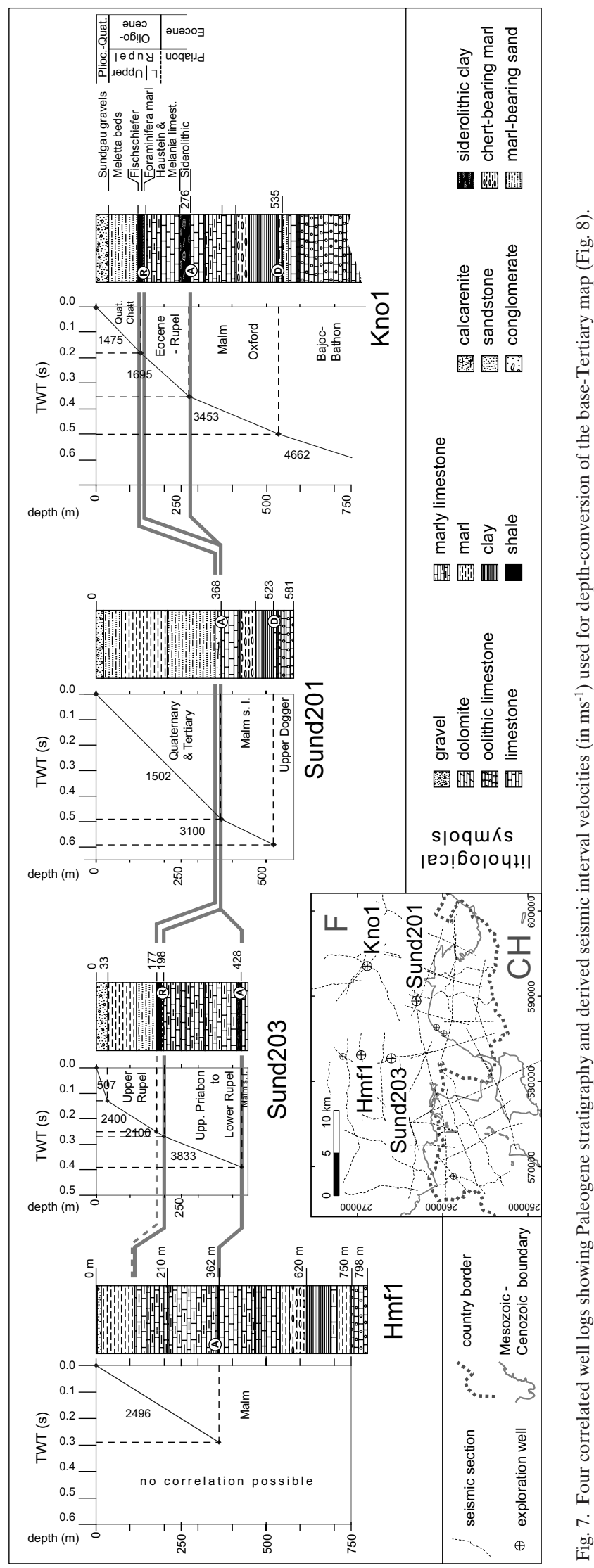

2.9 Ma (end of deposition of the Sundgau gravels, see above), minimum horizontal displacement rates in the order of 0.05 $\mathrm{mm} / \mathrm{a}$ can be deduced for the area covered by the three cross sections considered.

Vertical uplift rates may also be estimated along the Florimont and Réchésy anticlines, where the fold amplitude is in the order of $150 \mathrm{~m}$. Within the given time frame, this yields a minimum uplift rate that is also in the order of $0.05 \mathrm{~mm} / \mathrm{a}$. This estimate is in agreement with uplift rates that were deduced from the amount of uplift of Pleistocene alluvial terraces along the Largue, Ill and Thalbach Rhine tributaries, where they traverse anticline crests traceable in the Sundgau gravels (Giamboni et al. 2004b).

\subsection{Reactivation of pre-existing basement faults}

Dextral reactivation of an ENE-WSW-trending pre-existing basement fault system in the Pre-Mesozoic basement, that is part of the Permo-Carboniferous trough system and which was reactivated in the Paleogene as part of the Rhine-Bresse Transfer Zone, led to the formation of E-W-trending, en-échelon aligned surface anticlines of Post-Pliocene age (Florimont and Réchésy anticlines, Fig. 1). The field evidence for this dextral reactivation, supported by seismic data, is provided in Giamboni et al. (2004a, in particular their figs. 5 \& 7) and will not be repeated here.

Here we provide new evidence for left-lateral strike-slip reactivation of a differently oriented fault set, namely the NNEtrending ("Rhenish") faults, which parallel the URG master faults, formed in Paleogene times and pre-structured in the Late Paleozoic (Schumacher 2002).

An isolated anticline with an amplitude of approximately $20 \mathrm{~m}$, affecting the base of the Sundgau gravels, is located at a kink of the Illfurth fault (Fig. 3). This fault formed during Paleogene opening of the URG and represents the eastern limit of the Dannemarie Basin (Le Carlier de Veslud et al. 2005). Within the current stress field, the Illfurth fault is favourably oriented for accommodating sinistral strike-slip motion. Thus the isolated anticline probably formed at a restraining bend of the Illfurth fault (Fig. 3).

Further to the S, near Seppois le Haut in the Largue valley, conjugate normal faults are directly seen to affect the Sundgau gravel cover in a gravel pit (Fig. 5). As depicted in Fig. 3, this outcrop is located near the southernmost tip of the Illfurth fault. The normal faults affecting the Late Pliocene gravel cover are traceable by intercalated sand lenses in the grain-supported gravels (Fig. 5a and b). Smallscale normal faults with displaced markers allowed estimating the extension direction, which is NE-SW (Fig. 5c). Further south, in the Tabular Jura, a similarly oriented fault is found, but offset to the E with respect to the Illfurth fault. Hence, the formation of the conjugate normal faults is interpreted to have occurred at a releasing bend between two left stepping NNE-trending faults (bottom right inset in Fig. 3). 


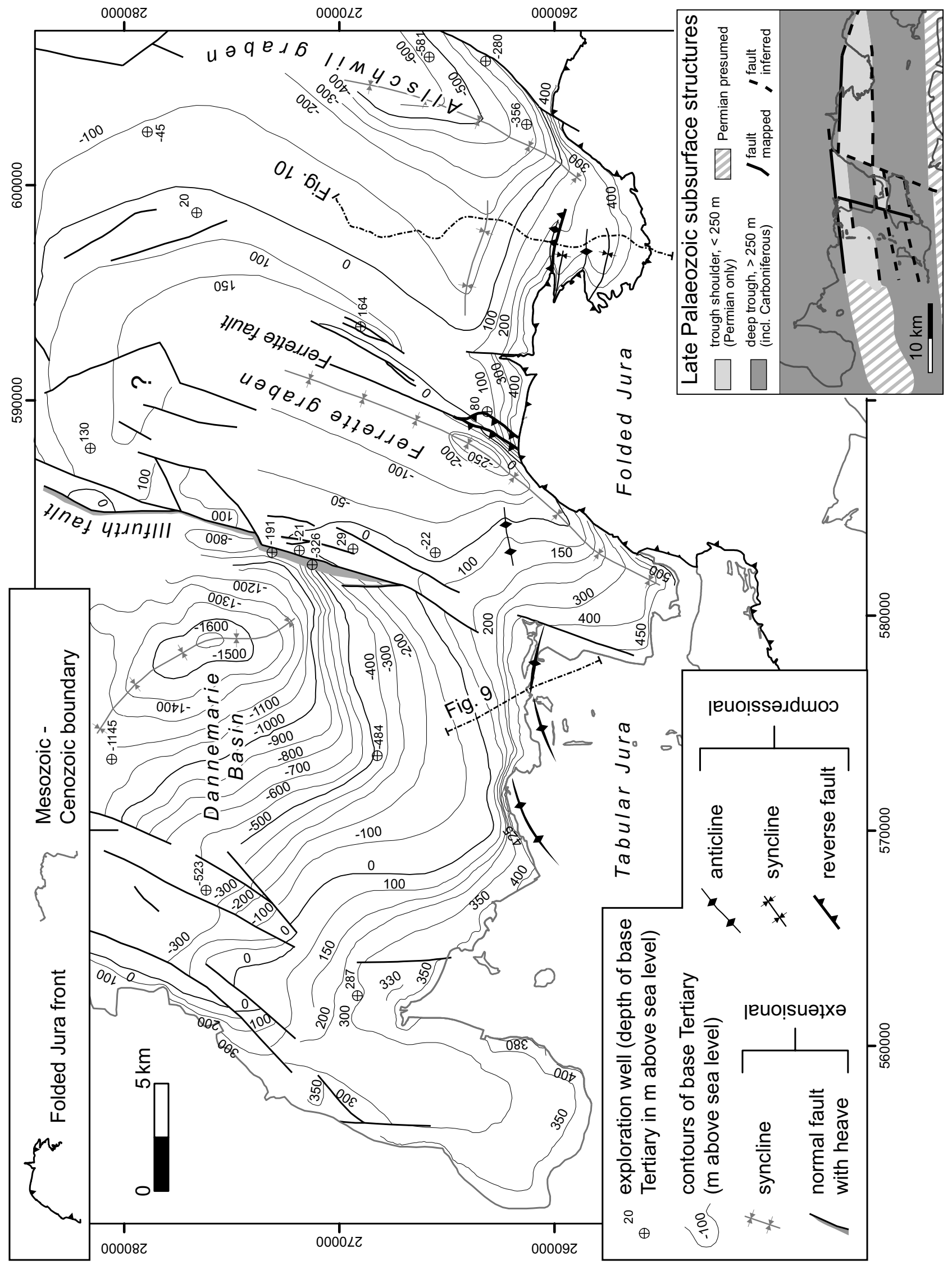

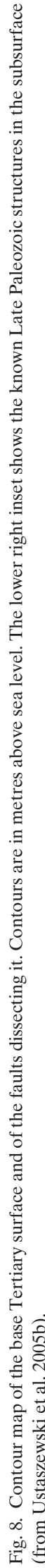



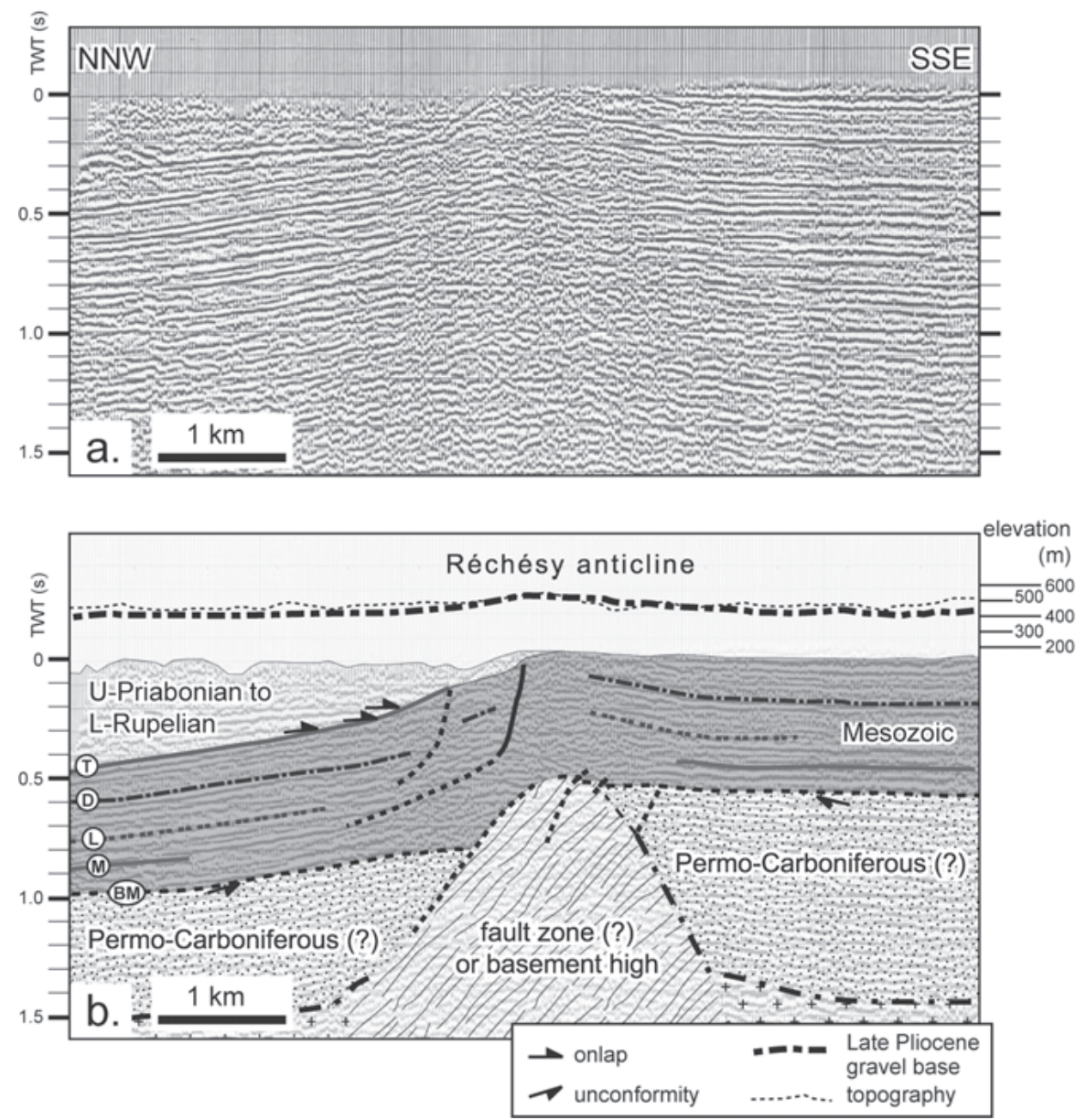

Fig. 9. Reflection seismic line across the Réchésy anticline (modified from Ustaszewski et al. 2005b). See Figures 6 and 8 for location of the section. a. Original stacked section. b. Interpreted section; $\mathrm{BM}=$ base Mesozoic, $\mathrm{M}=$ top Muschelkalk, $\mathrm{L}=$ top Lias, $\mathrm{D}=$ top Dogger, $\mathrm{T}=$ top Malm or base Tertiary, hatched=fault zone associated with late Paleozoic faults. Base of the Pliocene gravels (derived from the contour map, Fig. 3) and topography are superimposed. The vertical scale is exaggerated by a factor of 1.2 in order to coincide with the depth in s TWT (calculated using seismic velocities from boreholes nearby). Note the correlation between the dip of Mesozoic reflectors and the base of the gravels. Fold crests in both gravels and Mesozoic sediments coincide and are located precisely above a basement fault zone.
In summary, the existence of both restraining and releasing bends along the Illfurth fault hints at left-lateral strike-slip reactivation of the "Rhenish" fault system after the deposition of the Sundgau gravels. We interpret these movements to be concomitant with the dextrally transpressive reactivation of the ENE-trending faults that are part of the Rhine-Bresse Transfer Zone (Giamboni et al. 2004a).

\subsection{Is post-2.9 Ma deformation still ongoing at present?}

The Florimont and Réchésy anticlines are clearly discernible on a shaded relief map, using the Swiss $25 \mathrm{~m}$ digital terrain model (Figs. 6b, c). The topography of the anticlines essentially resulted from folding of Late Jurassic and Paleogene sediments. This can be judged from the close correlation between the strike of the hill slopes and the strike and dip measured in the Upper Jurassic and Paleogene sediments around the two anticlines (Fig. 6c). The contours of the base of the Sundgau gravels (Fig. 6d) also correlate very closely with topography. All this proofs that the topography formed after deposition of the Sundgau gravels, i.e. after 2.9 Ma. Moreover, the river courses of the Allaine and Coeuvatte are deflected away from the plunging crest of the Florimont anticline (Fig. 6b; Giamboni et al. 2004a, their fig. 4b).

Post-2.9 Ma shortening directions derived from paleostress analysis (Ustaszewski \& Schmid 2006) are roughly N-S oriented in the area of these two anticlines (black arrows in Fig. 6a). This is in agreement with present-day SHmax-orientations inferred from in-situ stress measurements in the sedimentary cover (Baumann 1981; Müller et al. 1987; Becker 1999, 2000; Reinecker et al. 2003; Fig. 2).

\section{Subsurface evidence for compressively reactivated basement faults}

\subsection{Contour map of the base of the Tertiary}

In order to further investigate the role of pre-existing basement faults within the southernmost URG during reactivations in a compressive and/or strike slip regime after Paleogene extension, a contour map of the base-Tertiary surface ("baseTertiary" for short) and of the faults dissecting this surface was 

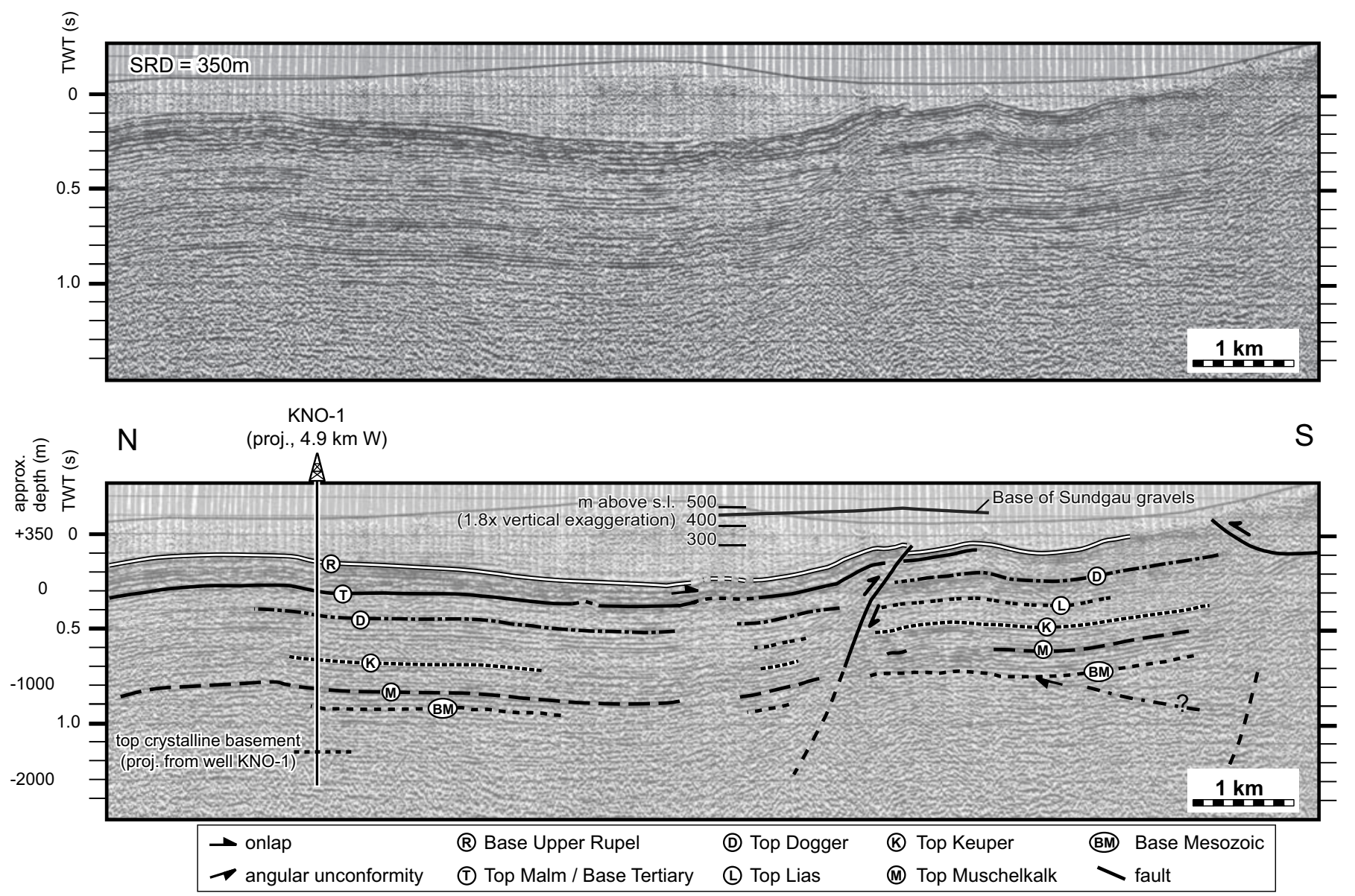

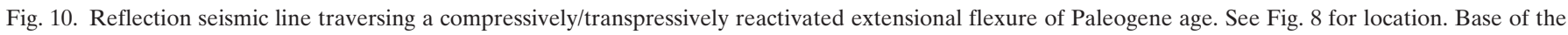

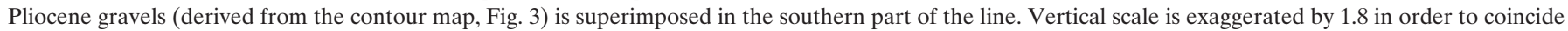

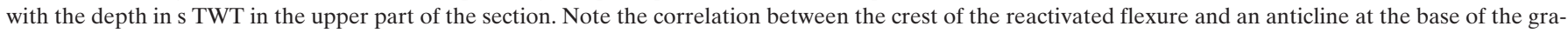
vels. This suggests that the shortening responsible for the folding of the Pliocene gravels is rooted in the basement.

compiled. 45 industry type reflection seismic lines located in the southernmost URG and the southerly adjacent Tabular and Folded Jura (see bottom centre inset in Fig. 7) were available for interpretation. Ten exploration wells (Schmidt et al. 1924; BRGM unpublished), aligned along or close to the seismic lines, enabled a correlation of seismic reflectors with lithologies encountered in exploration wells. Four of the wells that penetrated through the Tertiary succession allowed calculating seismic interval velocities (Fig. 7). The base of the Tertiary succession is marked by high acoustic impedance contrasts between the uppermost Mesozoic (mostly limestones) and lowermost Tertiary layers (often siderolithic clays). Locally, an angular unconformity is developed.

After identification of the base-Tertiary on the seismic lines, its depth (in seconds two-way-travel time, s TWT) was plotted on a map and contoured manually. In a further step, the contours were depth-converted using seismic velocities obtained on the four wells (Fig. 7). In the northwestern part, our base-Tertiary contour map (Fig. 8) was linked to the structural model of the Dannemarie Basin by Bourgeois et al. (2004). In the southernmost part, the base-Tertiary contours are essentially based on the available geological maps (Fischer 1965; Liniger 1970b; Ruhland et al. 1973; Bailly et al. 1985).

The depth of the base-Tertiary is found between $1600 \mathrm{~m}$ below sea level in the Dannemarie Basin and $500 \mathrm{~m}$ above sea level at the southwestern edge of the Ferrette Jura. The salient feature of Fig. 8 is the existence of three eastward tilted halfgrabens, each bounded by a NNE-trending normal fault in the east (Dannemarie, Ferrette and Allschwil grabens). These half-grabens developed gentle hanging-wall synclines, presumably due to drag along the bounding normal faults. Towards the Jura front, the base-Tertiary sways into an ENE-WSW to E-W trend along a zone of extensional flexures of the Mesozoic strata, underlain by Permo-Carboniferous faults (Fig. 8). This structural configuration is the result of Paleogene rifting and serves as a starting configuration for detecting later compressive reactivations. 


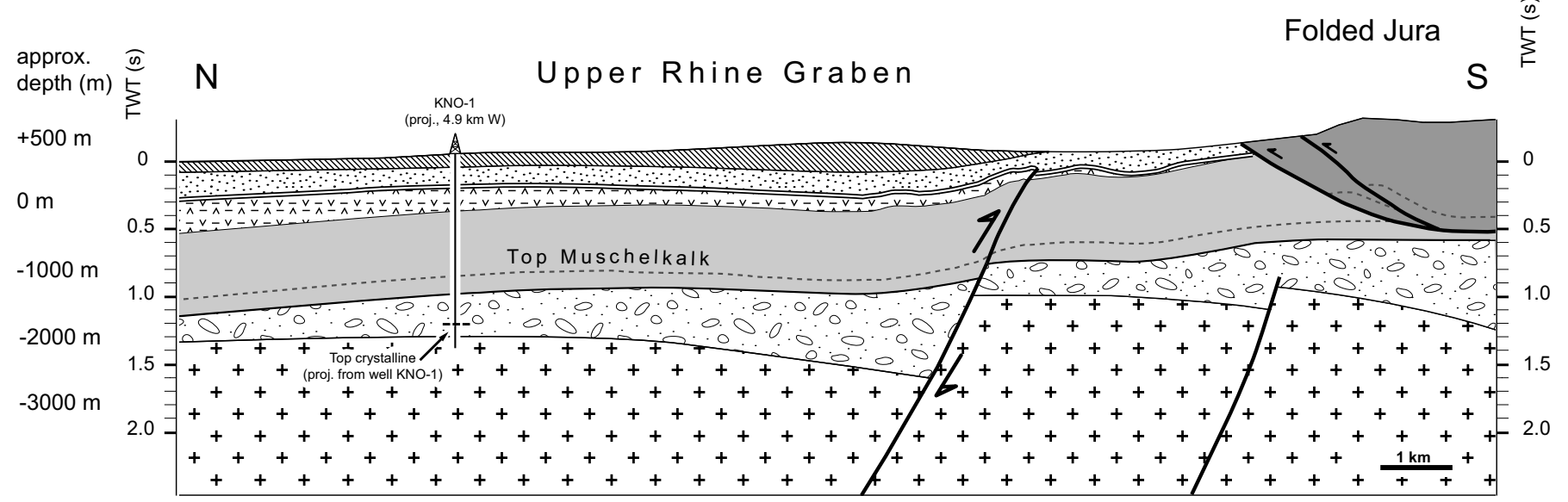

\begin{tabular}{lll} 
Chatt and Upper Pliocene & & $\begin{array}{l}\text { Base of Upper Rupelian (Foraminifera marl, } \\
\text { Fischschiefer, Meeressand) }\end{array}$ \\
\hdashline$\quad$ Upper Rupel ("Serie grise") & $=\begin{array}{l}\text { Upper Priabon - Lower Rupel } \\
\text { ("Salt Formation") }\end{array}$
\end{tabular}
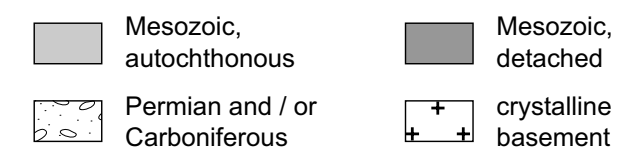

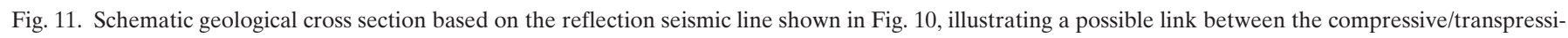
ve reactivation of an E-W-trending Paleogene extensional flexure and the incipient inversion of an underlying Permo-Carboniferous trough.

The normal fault bounding the Ferrette half-graben is clearly thrust by Mesozoic sediments along the W rim of the Ferrette Jura (Fig. 8). This is evidenced by boreholes (Schneegans \& Théobald 1948) and is interpreted to have occurred during the phase of thin-skinned Jura folding (Ustaszewski \& Schmid 2006, their fig. 15). However, immediately $\mathrm{N}$ of the northern tip of the Ferrette Jura, the Ferrette normal fault itself was reactivated. This is evidenced by two top-to-the-E reverse faults that splay off the Ferrette normal fault and which offset the base-Tertiary in seismic sections (see Ustaszewski et al. 2005b, their fig. 6). Since the splay faults dissect uppermost Rupélian and Chattian sediments, reactivation must have occurred after the Oligocene. On the other hand, the Sundgau gravel cover does not show any difference in elevation across these fault splays (compare Figs. 3 and 8). Hence the reactivation of this fault pre-dates the deposition of the Sundgau gravels. Moreover, the thin-skinned frontal thrust of the Ferrette Jura front appears to "seal" these compressive fault splays of the Ferrette fault. This hints at an Early Neogene reactivation, pre-dating the formation of the thin-skinned Jura fold-and-thrust belt.

At the eastern termination of the Ferrette Jura, the E-Wtrending anticlines plunge beneath the Tertiary infill of a small embayment of the URG that encroaches onto the Jura. At the southern limb of the northernmost of these gentle anticlines, a top-to-the-S reverse fault was mapped (Fischer 1965 and Fig. 8). This vergence is opposed to the transport direction of the detached sediments during the thin-skinned phase of Jura folding. As will be discussed below when presenting seismic evidence, this reverse fault post-dates the deposition of the Sundgau gravels and roots in the basement.

\subsection{Evidence from reflection seismic lines}

The compressive structures portrayed in Fig. 8 will now be discussed on the basis of reflection seismic data. The reflection seismic line across the Réchésy anticline (Fig. 9) complements another seismic line from the same area, crossing the westerly adjacent Florimont anticline (see Giamboni et al. 2004a, their fig. 7). The Réchésy anticline has a precursor as a Paleogene extensional flexure, documented by the S-ward tapering and onlap of Paleogene syn-rift sediments (Ustaszewski et al. $2005 \mathrm{~b}$ ). From the topography and the superimposed trend of the base of the Sundgau gravels (derived from Fig. 3), it is discernible that the topographic crest, the crest in the Sundgau gravel fold and the position of a relatively transparent basement fault zone (or high) underlying the Mesozoic succession all spatially coincide. This seismic evidence, together with that provided by Giamboni et al. (2004a), indicates that Paleogeneage extensional flexures have been compressively or transpressively reactivated after 2.9 Ma. Giamboni et al. (2004a) provided arguments that indicate reactivation of the basement fault itself. However, since a merely passive role of this basement fault zone depicted in Fig. 9 (and of that depicted in Giamboni et al. 2004a, their fig. 7) during a N-ward propagation of décollement tectonics across the formerly extensional flexure cannot be completely excluded, this issue needs to be further discussed together with additional seismic data presented below.

This additional reflection seismic line, trending approximately N-S along the Allschwil half-graben (Fig. 10, see Fig. 11 for a geological interpretation), provides unambiguous evi- 

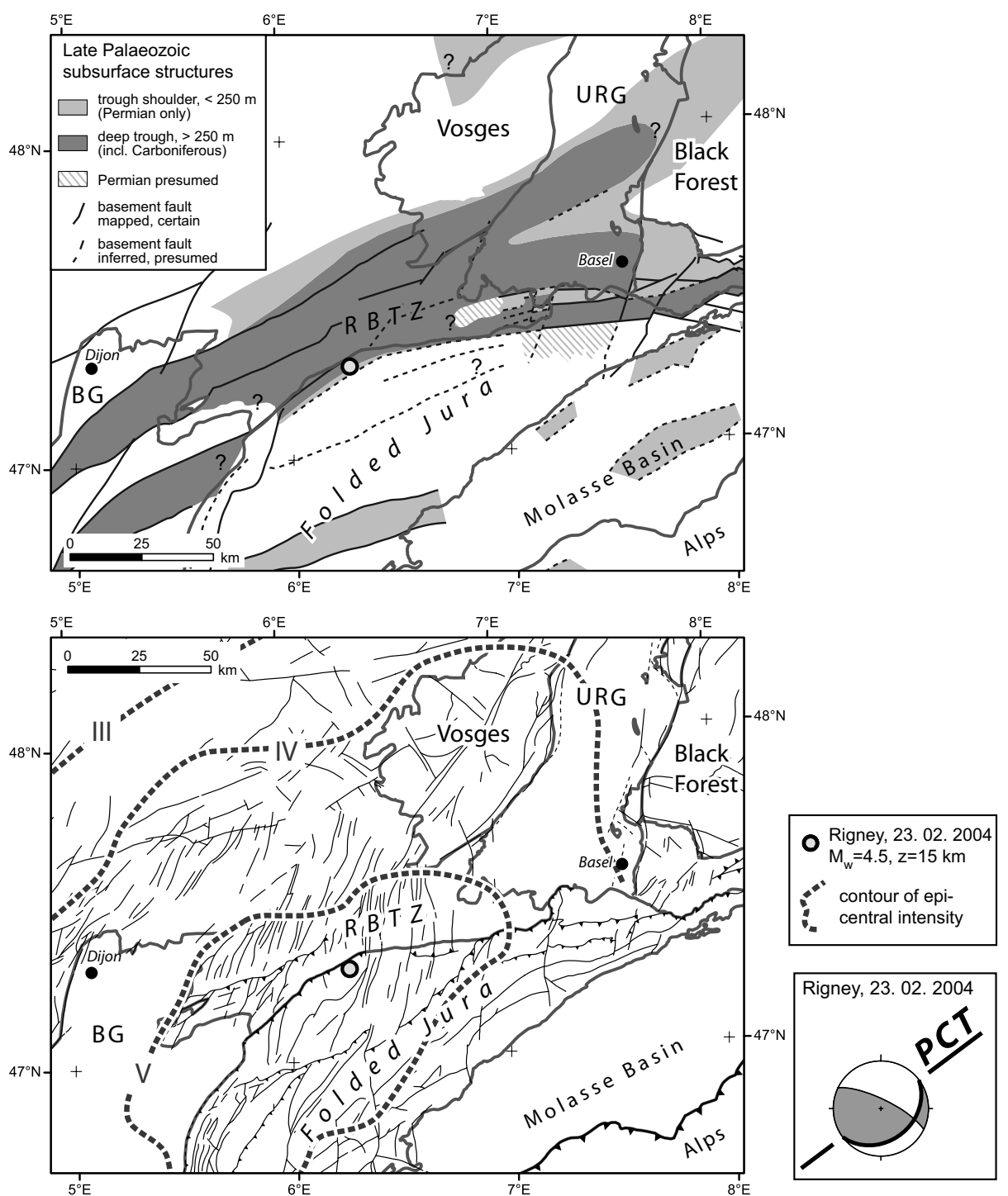

Fig. 12. Top: Late Paleozoic structures in the Rhine-Bresse Transfer Zone (RBTZ), superimposed onto the outlines of the major tectonic elements. $\mathrm{BG}=$ Bresse Graben, $\mathrm{URG}=$ Upper Rhine Graben. Bottom: location of the epicentre of the Rigney earthquake (Swiss Seismological Service 2004) and contours of epicentral intensity on the French territory (RéNaSS 2004), which are ellipsoidal with the long axis paralleling ENE-oriented subsurface faults. Map traces of faults reaching the surface (see top figure for subsurface faults) are shown in black. The focal mechanism (Swiss Seismological Service 2004; bottom right inset) is reverse faulting. Note that the ENE-trending, SE-dipping nodal plane (labelled "PCT" for Permo-Carboniferous trough) is again parallel to major subsurface basement faults in the epicentral area.

dence for basement-rooted neotectonic shortening. The southern end of the seismic line covers the Tertiary embayment east of the Ferrette Jura (Allschwil Graben). The Mesozoic succession reveals a constant thickness and gently rises in elevation from $\mathrm{N}$ to $\mathrm{S}$. A steeply $\mathrm{N}$-dipping basement fault offsets the base of the Tertiary at about $0.1 \mathrm{~s}$ TWT, corresponding to $\mathrm{c}$. 80-100 m depth. The Mesozoic succession was bent into an extensional flexure above this basement fault. The thickness of the Mesozoic succession is slightly lower on the hangingwallside (i.e. the $\mathrm{S}$ side) of the flexure when compared to the rest of the section. This extensional flexure was later covered by the onlapping Upper Priabonian to Lower Rupelian fill of the URG (between reflectors "T" and "R") that wedges out towards the $\mathrm{S}$. The weakly reflective to transparent parts above the " $\mathrm{R}$ " reflector are attributed to Uppermost Rupelian to
Chattian syn-rift sediments and the unconformably overlying Sundgau gravels. The extensional flexure was compressively reactivated by the top-to-the-S reverse fault that offsets the prominent Upper Rupelian reflector (Figs. 10 \& 11). The throw amounts to $0.05 \mathrm{~s}$ TWT, corresponding to some $40-50$ $\mathrm{m}$, given the seismic interval velocities valid for the Upper Oligocene syn-rift succession (Fig. 7). Based on the seismic information alone, this compressive (or transpressive) fault reactivation could have already occurred during latest Paleogene to Miocene times. However, note that the anticline in the hangingwall of this top-to-the-S reverse fault spatially coincides with an anticline defined by the contour lines of the base of the Sundgau gravels (compare Figs. 3 and 8). Moreover, the amplitude of the anticline contoured in Fig. 3 is identical to that detected in the seismic section (in the order of 30-50 m, 
see Figs. 10 and 11). Hence, we infer a post-2.9 Ma age for the compressional inversion of a pre-existing, roughly E-W trending basement fault. This fault is part of an ENE-WSW-trending pre-existing basement fault system within the Pre-Mesozoic basement (Permo-Carboniferous trough system), transtensionally reactivated by the Rhine-Bresse Transfer Zone in Paleogene times (Ustaszewski et al. 2005a,b).

\section{Discussion}

\subsection{Comparison of paleostress measurements with data on the present-day stress field}

The recent stress field in the sedimentary (Mesozoic to Tertiary) cover, as revealed by in-situ stress measurements, reveals NNW- over N- to NNE-oriented maximum horizontal stresses (SHmax, Figs. 2 and 3; see also Becker 1999, 2000). This spread in orientations within the cover rocks coincides with that of the shortening directions obtained from paleostress analysis (Fig. 2, see also Ustaszewski \& Schmid 2006), particularly in the area of the Folded Jura. Hence, no detectable reorientation of SHmax had occurred within the cover rocks since the onset of thinskinned Jura folding (in agreement with data provided by Becker 2000 and Müller et al. 2002).

However, at greater depth, i.e. within the basement of both URG and the Jura Mountains the direction of present-day SHmax, as derived from seismic events, is consistently NWSE-oriented (Plenefisch \& Bonjer 1997; Kastrup et al. 2004). Note that the present-day dextrally transpressive reactivation of the Rhine-Bresse Transfer Zone system, as inferred from this study and Giamboni et al. (2004a), also demands a present-day orientation of SHmax close to NW within the basement.

All this implies an anticlockwise rotation of present-day SHmax from cover to basement. Interestingly such stress decoupling is found to be systematic throughout northern Switzerland (Müller et al. 1987). It clearly indicates ongoing mechanical decoupling of the sedimentary cover from its basement along Mid- to Late Triassic weak layers. Whether such decoupling indeed indicates ongoing thin-skinned propagation of the Jura Mountains, as proposed by Müller et al. (2002), is another question. In view of the evidence provided in favour of thick-skinned tectonics we do not regard such decoupling between basement and cover as a solid argument for presently ongoing thin-skinned tectonics. Dynamically scaled sand-silicone models have demonstrated that low displacement rates along basement strike-slip faults also favour mechanical decoupling between basement and cover across a viscous weak décollement layer (Ustaszewski et al. 2005a). Given the low displacement rates that prevailed since the latest Pliocene, decoupling is also expected in a thick-skinned scenario according to these experiments.

We conclude that present-day deformation is thick-skinned and that the stress field is probably inhomogeneous, SHmax being NW-SE-oriented in the basement, but N-S in the cover.

\subsection{Kinematic framework of neotectonic activity in the southern URG}

The geometry of neotectonic deformations recorded by the stratigraphic base of the Sundgau gravels reveals an array of NE-SW- to ENE-WSW-oriented syn- and anticlines with amplitudes up to $150 \mathrm{~m}$. Retro-deformation of the anticlines yields amounts of shortening in the order of 1 to $3 \%$. Assuming shortening to have occurred between $2.9 \mathrm{Ma}$ and the present day, this yields minimum horizontal displacement rates in the order of $0.05 \mathrm{~mm} / \mathrm{a}$, corresponding to a strain rate in the order of $2 \cdot 10^{-16} \mathrm{~s}^{-1}$ across the folded area. This value is in agreement with strain rates calculated from GPS-derived velocities that are in the order of $4 \cdot 10^{-16} \mathrm{~s}^{-1}$ (Tesauro et al. 2005, their fig. 3).

The evidence for sinistral strike-slip faulting along NNEtrending faults (such as the Illfurth fault) after the latest Pliocene suggests that some folds that affect the base of the Sundgau gravels did form by sinistral wrench faulting.

The formation of the Florimont and Réchésy anticlines (Giamboni et al. 2004a and this work) and the backthrust formed further to the east (Figs. $10 \& 11$ ), in combination with ample geomorphologic evidence, suggests that at least much of the shortening across the ENE-WSW-trending basement faults of the Rhine-Bresse Transfer Zone occurred after deposition of the Sundgau gravels. The en-échelon arrangement of all the anticlines (Fig. 3), in combination with seismic evidence (Giamboni et al. 2004, their fig. 7; our Figs. 10 \& 11) favours the interpretation that this neotectonic shortening detected in the cover is caused by dextrally transpressive reactivation of the ENE-WSW-trending basement fault system of the RhineBresse Transfer Zone. The reverse fault portrayed in Fig. 10 is basement-rooted, which excludes the possibility that the compressive reactivation of the flexure is related to the ongoing $\mathrm{N}$ ward propagation of a décollement in the Triassic weak layers. In our opinion the profile of Fig. 10 represents the best evidence available so far in favour of a transition from thinskinned to thick-skinned deformation, which we infer to have occurred before the latest Pliocene.

The kinematic setting we propose for the neotectonic activity resembles that first proposed by Pavoni (1961) for the main phase of Jura folding; folding of the sedimentary cover may be linked to wrench faulting within a buried basement, provided that a ductile layer separates basement and cover. Such a layer is indeed provided by the Triassic evaporite horizons in the Jura Mountains and adjacent areas. Note, however, that we regard this scenario as a viable one only regarding the ongoing thick-skinned tectonic activity in the NW-foreland of the Alps (and not for the main phase of thin-skinned Jura folding).

Interestingly, the neotectonic reactivation of the Ferrette fault occurred where it interferes with the ENE-trending basement faults of the Rhine-Bresse Transfer Zone. This suggests that neotectonic shortening concentrated in an area where the NNE-trending sinistral reactivations interfere with concomi- 
tant dextrally transpressive reactivations along ENE-trending basement faults.

However, there is also evidence for pre-Late Pliocene compressive reactivation of the Rhine-Bresse Transfer Zone. An ENE-trending small anticline, identified in a seismic section presented by Ustaszewski et al. (2005a, their fig. 3), is located immediately $\mathrm{W}$ of the compressive splays of the Ferrette fault. This anticline formed along-strike with the Florimont and Réchésy anticlines, as well as the thrust depicted in Figs. $10 \& 11$ (see Fig. 8 for the location of all these compressive features). According to the seismic information, a purely post2.9 Ma age is unlikely, because the Sundgau gravel base reveals no upwarping above this particular anticline (compare Figs. 3 and 8). A first episode of dextrally transpressive reactivation of the underlying ENE-trending Rhine-Bresse Transfer Zone is likely to have predated the deposition of the Sundgau gravels. It probably pre-dated thin-skinned Jura tectonics and was possibly coeval with some sinistral reactivation of NNEtrending normal faults such as the Ferrette normal fault. Interestingly, such a first episode of compressive reactivation of URG-parallel basement faults was postulated by Laubscher (2001) to have occurred in Aquitanian to Burdigalian times in the case of Rheintal flexure located east of our working area. Moreover, on the seismic line portrayed in Fig. 9 one can depict that the S-dip of the Mesozoic reflectors at the southern limb of the anticline is slightly higher than the corresponding dip of the base of the Sundgau gravels. This suggests that an embryonic form of this anticline already formed prior to the folding of the Sundgau gravels. Hence, not all the shortening and uplift above the Rhine-Bresse Transfer Zone is of latest Pliocene to recent age. Unfortunately no continuous gravel sheet is preserved on top of the two above mentioned anticlines in order to quantify the amounts of Early Neogene versus neotectonic reactivation. However, the present geometry of the features presented in Figs. 10 \& 11 was essentially achieved during the second (neotectonic) phase of transpressive reactivation.

We conclude that the ENE-trending basement-rooted faults located at the southern end of the URG, related to the Rhine-Bresse Transfer Zone, appear to have been reactivated twice under compression in the Neogene. A first reactivation probably occurred in the early Neogene and pre-dated thinskinned Jura folding. The second and main phase of reactivation of ENE- to E-trending basement faults, however, postdates the deposition of the Sundgau gravels. This neotectonic activity is evidenced via the spatial coincidence between basement faults and folds mapped in both the base-Tertiary and base-Sundgau gravel maps, and additionally, by comparable fold amplitudes seen in both the base-Tertiary and the baseSundgau gravel surfaces.

The evidence for simultaneous neotectonic left-lateral strike-slip faulting along the NNE-trending Rhenish faults is in good agreement with seismotectonic evidence (Plenefisch \& Bonjer 1997; Deichmann et al. 2000a) that was mostly collected east of our working area. The coeval latest Pliocene to re- cent dextrally transpressive reactivation of the ENE-trending faults of the Rhine-Bresse Transfer Zone, as inferred from the present work, however, is hitherto supported almost exclusively by geological evidence (Meyer et al. 1994; Giamboni et al. 2004a; Ustaszewski et al. 2005a). The seismotectonic evidence supporting the reactivation of such ENE-trending faults is scarce in the area west of Basel, at least partly due to the lack of a dense network of permanent stations on French territory. Nevertheless, the February 02 ${ }^{\text {nd }} 2004$ earthquake in the RhineBresse Transfer Zone near Rigney (France), with a moment magnitude $\mathrm{Mw}=4.5$ and a focal depth of $15 \mathrm{~km}$, yielded a focal mechanism which indicates reverse faulting (Swiss Seismological Service 2004; Fig. 12). Although it is not admissible to assign one of the nodal planes to the actual fault plane without carefully analysing aftershocks, clear preference is given to the ENE-oriented and SE-dipping nodal plane labelled "PCT" in Fig. 12 because of the fact that ENE-trending basement faults related to the Permo-Carboniferous trough are abundant in this area. These faults are part of the Rhine-Bresse Transfer Zone (Debrand-Passard \& Courbouleix 1984). Thus, the focal mechanism of the Rigney earthquake can be regarded as seismotectonic evidence for the compressive inversion of PermoCarboniferous troughs in the northern Alpine foreland, compatible with dextral transpression along the Rhine-Bresse Transfer Zone as deduced from our data.

There are still more hints at dextrally transpressive neotectonic activity in the western part of the Rhine Bresse Transfer Zone. Based on reflection seismic data, Madritsch et al. (2007) reported the transpressive inversion of steep ENE-trending Paleozoic basement faults along the western part of the AvantMonts thrust, NW of Besançon. Surface structures associated with these inverted faults are gentle anticlines in the hangingwall of the Avant-Monts thrust. Uplift along these anticlines causes a northward deflection of the Ognon river, which flows immediately north of the Avant-Monts thrust, and the subsequent erosion of its presumably Pleistocene aggradational terraces (Campy 1984; Madritsch et al. 2005). These data seem thus in agreement with seismotectonic evidence from the Rigney 2004 event, concerning the neotectonic inversion of Permo-Carboniferous trough border faults.

Inversion of Permo-Carboniferous troughs is also compatible with ideas proposed by Ziegler (1990), Philippe (1994) and Pfiffner et al. (1997) for other parts of the NW foreland of the Alps located south of our working area. Note, however, that these authors proposed such thick-skinned reactivation for the main phase of Jura folding, that we consider as purely thinskinned. We postulate a thick-skinned kinematic framework only for neotectonic deformation, with a weak precursor in the Early Miocene, i.e. before the main phase of the thin-skinned formation of the Jura fold-and-thrust belt.

In case of the ENE-trending Mandach thrust in the eastern Tabular Jura ("M" in Fig. 1), located about $70 \mathrm{~km}$ east of our working area, but exactly along-strike above the eastern continuation of the Permo-Carboniferous trough, thick-skinned compressive neotectonic reactivation should at least not be 


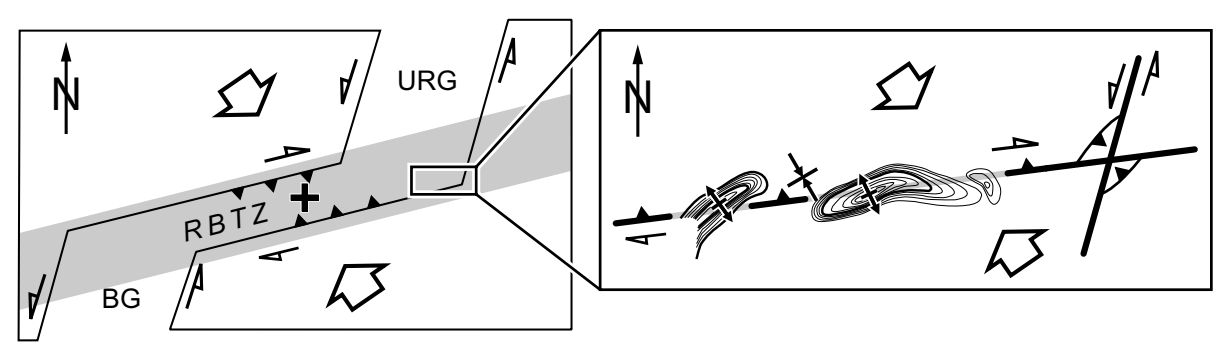

Fig. 13. Kinematic sketch proposed for the neotectonic activity in the study area. The RhineBresse Transfer Zone (RBTZ) is under dextral transpression, causing subsequent uplift ("+") due to the presumed inversion of ENE-trending Permo-Carboniferous troughs. En-échelon surface folds develop above ENE-trending basement faults. Simultaneously, NNE-trending faults of the URG-system are active as sinistral strike-slip faults. Transpressive fault splays or pop-ups develop at the intersection of the two differently oriented fault systems.

ruled out. According to most authors (Müller et al. 1984; Laubscher 1986; Sprecher \& Müller 1986; Diebold et al. 1991; Naef et al. 1995), the Mandach structure has initiated as an extensional flexure above the northern border fault of the Permo-Carboniferous trough, which later led to the nucleation of a thin-skinned, N-vergent thrust fault, concomitant with the formation of the Folded Jura further $\mathrm{S}$.

Haldimann et al. (1984) identified an ENE-trending ridge of easily erodible Aalenian clays underneath Pleistocene gravels along the Aare river in the eastern along-strike prolongation of the Mandach thrust. Haldimann (1987) treated the existence of this ridge as evidence for late Pleistocene uplift of the southern hangingwall along the Mandach thrust. Graf (1993) argued for an eastward deflection of $\mathrm{N}$-flowing Alpine rivers at the time of deposition of the "Höhere Deckenschotter". Based on paleoflow directions in a Pleistocene gravel sheet near Mandach, he related this deflection to uplift of the southern hangingwall along the Mandach thrust fault. In addition to this, precise levelling data indicate uplift of the "Vorfaltenzone" (i.e. the region between Mandach thrust and southerly adjacent thrust front of the Folded Jura; Müller et al. 2002). This led Müller et al. (2002) to consider the Mandach thrust as the northern tip of the "distant-push" front of the Folded Jura, which has remained active up to recent. However, as the thinskinned Mandach thrust is situated above the border fault of the Permo-Carboniferous trough (as is the case for the structures in the Rhine-Bresse Transfer Zone further W), neotectonic inversion of an underlying ENE-trending basement faults itself should not be completely ruled out, despite the lack of seismotectonic evidence for compressive reactivation in this area.

The seismotectonic evidence available for the area NE of Basel favours neotectonic reactivation of basement faults by strike slip and/or transtension (Plenefisch \& Bonjer 1997; Deichmann et al. 2000a; Kastrup et al. 2004). Hence the inferences regarding a transpressive neotectonic kinematic framework for our working area, located west of Basel, certainly do not apply to the area of the Black Forest and the eastern border fault of the URG.

In summary, and coming back to our area of investigation, the available geological evidence clearly shows that both the NNE-trending Rhenish faults and the ENE-trending basement faults of the Rhine-Bresse Transfer Zone were coevally reactivated during latest Pliocene to recent times. NNE-trending faults are reactivated in left-lateral strike-slip mode, the ENEtrending faults in dextrally transpressive strike-slip mode (occasionally thrusting as is the case for the 2004 Rigney earthquake).

\subsection{Which fault produced the Basel 1356 earthquake?}

The NW-SE-orientation of SHmax of the present-day stress field at depth appears well documented both by the interpretation of geological data such as that presented here and by seismotectonic evidence compiled by Kastrup et al. (2004). Together with our present knowledge regarding the orientation of pre-existing faults, this puts certain constraints as to which pre-existing fault might have been reactivated in which mode during the 1356 Basel earthquake. In view of the crucial importance of the high-magnitude Basel earthquake for seismic hazard evaluations, the quality of such evaluations critically depends on solving this difficult question.

Three sets of faults are prone to reactivation in the Basel area (Deichmann et al. 2004b). We argued that the NNEstriking Rhenish faults and the ENE-striking faults of the Rhine-Bresse Transfer Zone, which continue east of Basel into the Northern Swiss Permo-Carboniferous trough (e.g. Diebold \& Noack 1997; see also Ustaszewski et al. 2005b, their fig. 2), are presently active in terms of sinistral strike slip and dextrally transpressive movements, respectively. A third family of WNW-ESE-striking faults is found east of Basel only (see Fig. 12 top) and appears to be presently active there, as is for example suggested by fault plane solutions of the 1999 Pratteln and 2003 Zeiningen events (Deichmann et al. 2000b, 2004a), which are indicative for dextral strike slip reactivation. Although these WNW-ESE-striking faults are obviously active, their limited length on a geological map $(<40 \mathrm{~km})$ appears to be insufficient for creating the surface rupture length necessary for an earthquake with magnitude 6.5 or higher (Wells \& Coppersmith 1994; Deichmann et al. 2004b).

The data available so far do not allow to clearly decide between faults related to the ENE-striking Rhine-Bresse Transfer Zone (including its eastern continuation, the Northern 
Swiss Permo-Carboniferous trough) on the one hand and NNE-striking Rhenish faults on the other hand. Conspicuously, the epicentre of the 1356 Basel earthquake immediately south of Basel is located near the intersection of the two fault sets, suggesting mutual interactions between those two simultaneously active fault systems, such as was described above for the area west of Basel.

Both fault systems have been proposed as having provoked the 1356 Basel earthquake. Meyer et al. (1994) and Laubscher (2006) favour the Rhine-Bresse Transfer Zone, mainly based on the E-W elongated shape of the zones of equal damage (Mayer-Rosa \& Cadiot 1979). They left it open as to whether this fault system was reactivated in dextral strike slip or thrust mode. Answering this question would demand knowledge of the ratio and orientation of the principal stresses such as can be obtained through inversion of fault plane solutions for seismic events. So far such data (Kastrup et al. 2004) are only available for the areas north of Basel (strike slip mode) and south of Basel (combination of strike slip and normal faulting). Our evidence for dextral transpression along the Rhine-Bresse Transfer Zone west and southwest of Basel, together with the fault plane solution of the Rigney 2004 earthquake, rather suggests a combination of strike slip and thrusting for the present-day stress field in the area west of Basel, a stress field that might also have triggered the 1356 Basel earthquake. In view of the relatively larger strain accumulation we detected above faults related to the Rhine-Bresse Transfer Zone system regarding latest Pliocene to recent deformations, we favour the hypothesis that it is this fault system, which was activated, in agreement with the ideas proposed by Meyer et al. (1994) and Laubscher (2006). The most probable mode of reactivation is dextral transpression (Fig. 13).

On the other hand, we cannot exclude reactivation of one of the NNE-striking Rhenish faults during the 1356 Basel event in sinistral strike slip mode. However, we agree with Laubscher (2006) that the evidence for a reactivation of a Rhenish fault in extensional mode during the Basel earthquake (the so-called "Reinach fault") provided by Meghraoui et al. (2001) and Ferry et al. (2005) is incompatible with our knowledge about the present-day stress field. As pointed out by Laubscher (2006) the evidence provided by Meghraoui et al. (2001) and Ferry et al. (2005) for the "Reinach fault" being an active seismogenic fault is far from convincing. The geomorphological features found in the surroundings of the "Reinach fault" rather indicate that gravitational sliding was responsible for the "faults" documented by the trenching (Ferry et al. 2005).

In conclusion, a dextrally transpressive reactivation of a fault that is part of the ENE-striking Rhine-Bresse Transfer Zone is a possible candidate for having caused the 1356 Basel earthquake (Fig. 13). Reactivation of a NNE-striking Rhenish fault cannot be excluded. However, such a reactivation would be expected in sinistral strike slip rather than normal fault mode.

\subsection{What induced the change from thin-skinned to thick-skinned deformation in the Late Pliocene?}

Our data, together with those presented by Giamboni et al. (2004a), Ustaszewski et al. (2005a) and Ustaszewski \& Schmid (2006) provide compelling evidence for basement-rooted fault reactivation to have followed Late Miocene to Early Pliocene thin-skinned folding and thrusting. Thick-skinned reactivation is particularly well documented in an ENE-trending belt of basement faults that delineate the Permo-Carboniferous graben system in the subsurface, roughly paralleling the northern front of the eastern Jura Mountains (see top of Fig. 12, and Ustaszewski et al. 2005b, their fig. 2). The data suggest that this transition is linked to the incipient inversion of these grabens. This implies that shortening within the pre-Mesozoic basement, which took place within the Alps during classical Jura folding ("Fernschub" or "distant push" theory in the sense of Laubscher 1961), migrated northwards into the Alpine foreland during the Late Pliocene. Based on evidence from reflection seismic profiles and cross section balancing considerations, inversion of Permo-Carboniferous grabens during a late stage or, alternatively, post-dating thin-skinned Jura folding and thrusting, was also invoked for the basement underneath the western Jura belt (Philippe 1994; Philippe et al. 1996). In the following, we speculate on the reasons that might have led to this transition from thin-skinned tectonics to basement-rooted deformation. Two possibilities are briefly outlined: (1) deactivation of intra-crystalline glide along the basal décollement, and (2) ongoing tectonic underplating in the foreland of the northwestern Alps (Mosar 1999).

(1) The theory that décollement in the Jura fold- and thrust belt occurred by viscous flow, i.e. processes such as intracrystalline glide within the Mid- and Upper Triassic halite and anhydrite layers, is rheologically viable and widely accepted nowadays (Laubscher 1961; Müller \& Briegel 1980; Jordan 1987). Intracrystalline glide processes in some of the evaporites may be activated at very low temperatures that are equivalent to an overburden column in the order of $1 \mathrm{~km}$. Based on apatite fission track data, 1-3 km of uplift and erosion of the entire Swiss Molasse Basin after 5 Ma BP were recently documented (Cederbom et al. 2004). According to these authors, the uplift was triggered by accelerated erosion in the Swiss Alps in response to increased precipitation rates, leading to the isostatic rebound of the Alps together with the northerly adjacent foreland basin. This high amount of erosion in the northern Molasse Basin may have caused the sedimentary overburden (and, hence, the temperature) to fall beneath a critical threshold necessary to keep intracrystalline glide systems in the basal Jura décollement active. The inferred timing of the uplift slightly predates the onset of sedimentation of the Pliocene Sundgau gravels at 4.2 Ma ago, which, in turn, is thought to be the latest possible time at which thin-skinned folding in the Northern Jura Mountains has come to a halt (Becker, 2000; Ustaszewski \& Schmid 2006). These timing constraints allow a causal relationship between rebound-triggered 
exhumation in the Molasse Basin and cessation of thin-skinned Jura folding.

(2) A crustal-scale transect across the northwestern Alps, including the Molasse Basin and the Jura fold and thrust belt, exhibits a steep basal frontal thrust below the external massifs and a very narrow frontal portion (Mosar 1999), an overall geometry that is believed to be unstable when analyzed in terms of the critical taper theory (Chappel 1978; Davis et al. 1983; Dahlen \& Suppe 1988). By integrating geodetically determined uplift rates and the seismicity distribution, Mosar (1999) proposed that the Alpine orogenic wedge is currently in the process of accreting new basement nappes from the European crust at its base (below the Jura-Molasse transition) in an attempt to regain stability. If true, the propagation of such incipient thrust faults towards the foreland has conceivably already reached the area of the external Jura fold-and-thrust belt, as revealed by the reverse faulting mechanism of the $\mathrm{Mw}=4.5$ earthquake in the Rhine-Bresse Transfer Zone on February $23^{\text {rd }} 2004$ (Fig. 12), with a focal depth of c. $15 \mathrm{~km}$ (Swiss Seismological Service 2004; Baer et al. 2005).

\section{Conclusions}

(1) The southern URG experienced thick-skinned reactivation of WSW-ENE and NNE-SSW-striking faults since the Late Pliocene. NNE-SSW-trending faults were reactivated in sinistral strike slip mode; WSW-ENE-trending faults were reactivated by dextral transpression. Reactivation of the WSWENE-striking system (Rhine-Bresse Transfer Zone) predominates. These faults border an extensive Permo-Carboniferous trough system, hinting at its incipient inversion.

(2) The present-day stress field, as derived from focal mechanisms, indicates NW-SE-directed SHmax in the basement. N-S-directed SHmax is indicated for the cover by in-situ stress measurements and paleostress analysis.

(3) Restoration of the gently folded base of the gravels yields minimum horizontal displacement rates in the order of $0.05 \mathrm{~mm} / \mathrm{a}$, corresponding to a strain rate in the order of $2 \cdot 10^{-16} \mathrm{~s}^{-1}$. Geomorphological evidence strongly suggests that this deformation is still ongoing at present.

(4) Dextrally transpressive reactivation of a fault that is part of the ENE-striking Rhine-Bresse Transfer Zone is the most likely candidate for having caused the 1356 Basel earthquake, while reactivation of a NNE-striking Rhenish fault in sinistral strike slip mode cannot be excluded.

(5) A geodynamic reorganization took place during the Late Pliocene. This reorganization apparently led to the deactivation of the basal décollement in the Triassic and (subsequently or simultaneously) to the compressive inversion of formerly extensional basement faults in the Alpine foreland. It is speculated that one or a combination of the following factors might have induced this change: (a) post-5 Ma uplift of the Molasse Basin and concomitant erosion of 1-3 km of its Tertiary infill (Cederbom et al. 2004), eventually leading to a temperature decrease within the viscously deforming basal dé- collement horizon and consequently a rise of basal shear stress above a critical threshold; (b) propagation of incipient thrust faulting towards the foreland, i.e. into the area of the external Jura fold-and-thrust belt, due to ongoing tectonic underplating of European crust in the foreland of the north-western Alps (Mosar 1999).

\section{Acknowledgments}

This contribution is dedicated to the memory of Martin Burkhard, with whom we repeatedly had stimulating discussions on the topic, even if our conclusions deviated. Marc Schaming (EOST Strasbourg) is greatly thanked for facilitating access to seismic data, which is the courtesy of Shell International EP and Enterprise Oil. This study is a contribution to the EUCOR-URGENT (Upper Rhine Graben Evolution and Neotectonics) project and benefited from logistic and financial support by the European Union-funded ENTEC (Environmental Tectonics) research and training network. We particularly acknowledge financial funding for K. U. by Swiss grant BBW 99-0567-1. We also thank numerous colleagues from the EUCOR-URGENT team in Basel, particularly Peter Ziegler and Pierre Dèzes for many fruitful discussions and their ongoing support. S. Sch. thanks D. Slejko (Trieste), N. Deichmann (ETH Zürich) and W.H. Müller (NAGRA) for many fruitful discussions regarding neotectonics and seismic hazard. W.H. Müller and an anonymous colleague are also thanked for their very critical reviews that helped to improve this manuscript.

\section{REFERENCES}

Baer, M., Deichmann, N., Braunmiller, J., Husen, S., Fäh, D., Giardini, D., Kästli, P., Kradolfer, U. \& Wiemer, S. 2005: Earthquakes in Switzerland and surrounding regions during 2004. Eclogae Geologicae Helvetiae 98, 407-418.

Bailly, C., Chauve, P. \& Martin, J. 1985: Carte Géologique de la France à 1/50 000, Delle, feuille XXXVI-22. Ministère de'l industrie et de la recherche, Bureau de recherches géologiques et minières, Service Géologique National, Orléans.

Baumann, H. 1981: Regional Stress Field and Rifting in Western Europe. Tectonophysics 73, 105-111.

Becker, A. 1999: In Situ Stress data from the Jura mountains - new results and interpretation. Terra Nova 11, 9-15.

Becker, A. 2000: The Jura Mountains - an active foreland fold-and-thrust belt? Tectonophysics 321, 381-406.

Bergerat, F. \& Chorowicz, J. 1981: Etude des images Landsat de la zone tranformante Rhin-Saône (France). Geologische Rundschau 70, 354-367.

Bourgeois, O., Le Carlier de Veslud, C., Ford, M. \& Diraison, M. 2004: 3D modelling of the Dannemarie Basin, Nancy. http://www.crpg.cnrsnancy.fr/MODEL3D/rhine.html, accessed on 01-01-2004.

BRGM, unpublished. Banque du sous-sol, accessed at the EOST Strasbourg.

Burkhard, M. 1990: Aspects of the large-scale Miocene deformation in the most external part of the Swiss Alps (Subalpine Molasse to Jura fold belt). Eclogae Geologicae Helvetiae 83, 559-583.

Burkhard, M. \& Sommaruga, A. 1998: Evolution of the western Swiss Molasse basin: structural relations with the Alps and the Jura belt. In: Mascle, A. Puidgefàbregas, C., Luterbacher, H.P. \& Fernàndez, M. (Eds), Cenozoic Foreland Basins of Western Europe. Geological Society Special Publications 134, 279-298.

Buxtorf, A. 1907: Geologische Beschreibung des Weissenstein-Tunnels und seiner Umgebung. Beiträge zur Geologischen. Karte der Schweiz, NF 21. $147 \mathrm{pp}$.

Campy, M. 1984: Signification dynamique et climatique des formations et terrasses fluviatiles dans un environnement de moyenne montagne. Bulletin de l'Association française pour l'Étude du Quaternaire 1, 87-92.

Cederbom, C.E., Sinclair, H.D., Schlunegger, F. \& Rahn, M. 2004: Climate-induced rebound and exhumation of the European Alps. Geology 32, 709-712, doi: 10.1130/G20491.1. 
Chappel, W.M. 1978: Mechanics of thin-skinned fold-and-thrust belts. Geological Society of America Bulletin 89, 1189-1198.

Dahlen, F.A. \& Suppe, J. 1988: Mechanics, growth and erosion of mountain belts. In: Clark, S.P., Burchfiel, B.C. \& Suppe, J. (Eds.): Processes in continental lithospheric deformation, Volume 218: Geological Society of America Special Paper, Geological Society of America, 161-178.

Davis, D., Suppe, J. \& Dahlen, F.A. 1983: Mechanics of fold-and-thrust belts and accretionary wedges. Journal of Geophysical Research 88, 1153-1172.

Debrand-Passard, S. \& Courbouleix, S. 1984: Synthèse Géologique du SudEst de la France, volume 2: Atlas comprenant 64 planches en couleurs. Mémoire du Bureau de recherches géologiques et minières 126, 614.

Deichmann, N., Ballarin Dolfin, D. \& Kastrup, U. 2000a: Seismizität der Nord- und Zentralschweiz. NAGRA Technischer Bericht 00-05. NAGRA, Wettingen, $94 \mathrm{pp}$.

Deichmann, N. \& 17 co-authors 2000b: Earthquakes in Switzerland and surrounding regions during 1999. Eclogae Geologicae Helvetiae 93, 395-406.

Deichmann, N. \& 18 co-authors 2004a: Earthquakes in Switzerland and surrounding regions during 2003. Eclogae Geologicae Helvetiae 97, 447-458.

Deichmann, N., Slejko, D. \& Schmid, S.M. 2004b: SP1 Seismic Source Characterisation, Elicitation Summary of expert team EG1a. PEGASOS Project Report Vol. 3. Unpublished work available from the third author.

Dèzes, P., Schmid, S.M. \& Ziegler, P.A. 2004: Evolution of the European Cenozoic Rift System: interaction of the Alpine and Pyrenean orogens with their foreland lithosphere. Tectonophysics 389, 1-33.

Diebold, P. 1988: Der Nordschweizer Permokarbon-Trog und die Steinkohlefrage der Nordschweiz. Vierteljahrsschrift der naturforschenden Gesellschaft Zürich 133, 143-174.

Diebold, P. \& Naef, H. 1990: Der Nordschweizer Permokarbontrog. Nagra informiert 2, 29-36.

Diebold, P., Naef, H., Ammann, M. 1991: Zur Tektonik der zentralen Nordschweiz. Interpretation aufgrund regionaler Seismik, Oberflächengeologie und Tiefbohrungen. NAGRA Technischer Bericht 90-04. Nagra, Wettingen and Landeshydrologie und -geologie, Bern, Geologischer Bericht Nr. 14. $300 \mathrm{pp}$

Diebold, P. \& Noack, T. 1997: Late Paleozoic troughs and Tertiary structures in the Eastern Folded Jura. In: Pfiffner, O.A., Lehner, P., Heitzmann, P., Mueller, S. \& Steck, A. (Eds): Deep structure of the Swiss Alps. Results of NRP 20. Birkhäuser, 59-63.

Doebl, F. 1970: Die tertiären und quartären Sedimente des südlichen Rheingrabens. In: Illies, J.H. \& Mueller, S. (Eds): Graben Poblems. Proceedings of an International Rift Symposium held in Karlsruhe October, 10-12, 1968. E. Schweizerbart'sche, Stuttgart, 56-66.

Fejfar, O., Heinrich, W.D. \& Lindsay, E.H. 1998: Updating the Neogene rodent biochronology in Europe. Mededelingen Nederlands Instituut voor Toegepaste Geowetenschappen 60, 533-554.

Ferry, M., Meghraoui, M., Delouis, B. \& Giardini, D. 2005: Evidence for Holocene palaeoseismicity along the Basel-Reinach active normal fault (Switzerland): a seismic source for the 1356 earthquake in the Upper Rhine graben. Geophysical Journal International 160, 554-572.

Fischer, H. 1965: Geologischer Atlas der Schweiz 1:25 000, Atlasblatt 49, Rodersdorf, mit Erläuterungen. Schweizerische Geologische Kommission, Bern.

Giamboni, M., Ustaszewski, K., Schmid, S.M., Schumacher, M.E. \& Wetzel, A. 2004a: Plio-Pleistocene Transpressional Reactivation of Paleozoic and Paleogene Structures in the Rhine-Bresse transform Zone (northern Switzerland and eastern France). International Journal of Earth Sciences 93, 207-223, doi: 10.1007/s00531-003-0375-2.

Giamboni, M., Wetzel, A., Nivière, B. \& Schumacher, M.E. 2004b: Plio-Pleistocene folding in the southern Rhinegraben recorded by the evolution of the drainage network (Sundgau area; Northwestern Switzerland and France). Eclogae Geologicae Helvetiae 97, 17-31, doi: 10.1007/s00015004-1112-4.

Graf, H.R. 1993: Die Deckenschotter der zentralen Nordschweiz. PhD Thesis, ETH Zürich, 151 pp.

Haldimann, P., Naef, H. \& Schmassmann, H. 1984: Fluviatile Erosions- und Akkumulationsformen als Indizien jungpleistozäner und holozäner Bewegungen in der Nordschweiz und angrenzenden Gebieten. NAGRA Technischer Bericht 84-16: Wettingen, Nagra, 112pp.
Haldimann, P. 1987: Indizien für neotektonische Krustenbewegungen in der Nordschweiz. Eclogae Geologicae Helvetiae 80, 509-519.

Illies, J.H. 1981: Mechanism of Graben formation. Tectonophysics 73, 249-266.

Jordan, P. 1987: Eine Methode zur Abschätzung tektonischer Scherraten aufgrund mikrostruktureller Beobachtungen. Eclogae Geologicae Helvetiae 80, 491-508.

Jordan, P. 1992: Evidence for large-scale decoupling in the Triassic evaporites of Northern Switzerland: An overview. Eclogae Geologicae Helvetiae 85, 677-693.

Kastrup, U., Zoback, M.L., Deichmann, N., Evans, K.F., Giardini, D. \& Michael, A.J. 2004: Stress field variations in the Swiss Alps and the northern Alpine foreland derived from inversion of fault plane solutions. Journal of Geophysical Research 109(B01402), doi:10.1029/2003JB002550.

Lacombe, O., Angelier, J., Byrne, D. \& Dupin, J. 1993: Eocene-Oligocene tectonics and kinematics of the Rhine-Saône continental transform zone (Eastern France). Tectonics 12, 874-888.

Lambert, J., Winter, T., Dewez, T. \& Sabourault, P. 2005: New hypotheses on the maximum damage area of the 1356 Basel earthquake (Switzerland). Quaternary Science Reviews 24, 381-299.

Laubscher, H. 1961: Die Fernschubhypothese der Jurafaltung. Eclogae Geologicae Helvetiae 54, 222-282.

Laubscher, H. 1972: Some overall aspects of Jura dynamics. American Journal of Science 272, 293-304.

Laubscher, H. 1973: Faltenjura und Rheingraben: zwei Grossstrukturen stossen zusammen. Jahresbericht und Mitteilungen des oberrheinischen geologischen Vereins 55, 145-158.

Laubscher, H. 1986: The eastern Jura: Relations between thin-skinned and basement tectonics, local and regional. Geologische Rundschau 75, 535-553.

Laubscher, H. 2001: Plate interactions at the southern end of the Rhine graben. Tectonophysics 343,1-19.

Laubscher, H. 2006: Zur Geologie des Erdbebens von Basel. In: Meier W.(Ed.): Da verfiele Basel überall. 184. Neujahrsblatt der GGG Basel, Schwabe Verlag Basel, 207-230.

Laubscher, H. \& Noack, T. 1997: The deep structure of the Basel Jura. In: Pfiffner, O.A., Lehner, P., Heitzmann, P., Mueller, S. \& Steck, A. (Eds), Deep structure of the Swiss Alps. Results of NRP 20. Birkhäuser, 54-58.

Le Carlier de Veslud, C., Bourgeois, O., Diraison, M., \& Ford, M. 2005: 3D stratigraphic and structural synthesis of the Dannemarie basin (Upper Rhine Graben). Bulletin de la Société géologique de France 176, 433-442.

Liniger, H. 1963: Geologische Beobachtungen in der Ajoie (Berner Jura). Regio Basilensis 4, p. 39-47.

Liniger, H. 1964: Beziehungen zwischen Pliozän und Jurafaltung in der Ajoie. Eclogae Geologicae Helvetiae 57, 75-90.

Liniger, H. 1966: Das plio-altpleistozäne Flussnetz der Nordschweiz. Regio Basilensis 7, p. 158-177.

Liniger, H. 1970a: Bemerkungen zur Tektonik am Südende des Rheingrabens. In: Illies, J.H. \& Mueller, S. (Eds): Graben Problems. Proceedings of an International Rift Symposium held in Karlsruhe 1968, International Upper Mantle Project. Scientific Report. E. Schweitzerbart'sche, Stuttgart, 103-106.

Liniger, H. 1970b: Geologischer Atlas der Schweiz 1:25 000, Atlasblatt 55: Bonfol, mit Erläuterungen. Kümmerly \& Frey, Bern.

Lopes Cardozo, G.G.O. \& Granet, M. 2003: New insight in the tectonics of the southern Rhine Graben-Jura region using local earthquake seismology. Tectonics 22, 1078, doi:10.1029/ 2002TC001442.

Madritsch, H., Molliex, S., Fabbri, O., Preusser, F. \& Schmid, S.M. 2005: River deflections in the Rhine-Bresse transfer zone (Franche Comté) - Geomorphic expression of thick-skinned faulting in the northern Alpine foreland?. In: Lacombe, O., Lavé, J. \& Roure, F. (Eds): Thrust Belts and Foreland Basins, SGF-SGE Joint Earth Science Meeting, Ruel-Malmaison (France), Abstract volume, 242-243.

Madritsch, H., Schmid, S.M. \& Fabbri, O. 2007: Inheritance of Paleozoic basement structures in the northwestern Alpine foreland (Eastern France) Paleogene transtensive reactivation and Neogene to recent transpressive inversion. Geophysical Research Abstracts 9, SRef-ID: 1607-7962/gra/ EGU2007-A-02065. 
Manz, O. 1936: Die Ur-Aare als Oberlauf und Gestalterin der pliozänen Oberen Donau. PhD thesis, Eberhard-Karls Universität Tübingen, 227 pp.

Mayer-Rosa, D. \& Cadiot, B. 1979: Review of the 1356 Basel earthquake: basic data. Tectonophysics 53, 325-333.

Meghraoui, M., Delouis, B., Ferry, M., Giardini, D., Huggenberger, P. \& Spottke, I. 2001: Active normal faulting in the Upper Rhine Graben and paleoseismic identification of the 1356 Basel earthquake. Science 293, 2070-2073.

Meyer, B., Lacassin, R., Brulhet, J. \& Mouroux, B. 1994: The Basel 1356 earthquake: which fault produced it? Terra Nova 6, 54-63.

Mosar, J. 1999: Present-day and future tectonic underplating in the western Swiss Alps: reconciliation of basement/wrench-faulting and décollement folding of the Jura and Molasse basin in the Alpine foreland. Earth and Planetary Science Letters 173, 143-155.

Müller, W.H. \& Briegel, U. 1980: Mechanical aspects of the Jura overthrust. Eclogae Geologicae Helvetiae 73, 239-250.

Müller, W.H., Huber, M., Isler, A. \& Kleboth, P. 1984: Erläuterung zur Geologischen Karte der zentralen Nordschweiz 1:100'000. NAGRA Technischer Bericht 84-25. NAGRA, Wettingen.

Müller, W.H., Blümling, P., Becker, A. \& Clauss, B. 1987: Die Entkoppelung des tektonischen Spannungsfeldes an der Jura-Überschiebung. Eclogae Geologicae Helvetiae 80, 473-489.

Müller, W.H., Naef, H. \& Graf, H.R. 2002: Geologische Entwicklung der Nordschweiz, Neotektonik und Langzeitszenarien, Zürcher Weinland. NAGRA Technischer Bericht 99-08. NAGRA, Wettingen, 226 pp.

Naef, H., Birkhäuser, P., Roth, P. 1995: Interpretation der Reflexionsseismik im Gebiet nördlich Lägeren - Zürcher Weinland. NAGRA Technischer Bericht 94-14. Nagra, Wettingen, $120 \mathrm{pp}$.

Nivière, B. \& Winter, T. 2000: Pleistocene northwards fold propagation of the Jura within the southern Upper Rhine Graben: seismotectonic implications. Global and Planetary Change 27, 263-288.

Pavoni, N. 1961: Faltung durch Horizontalverschiebung. Eclogae Geologicae Helvetiae 54, 515-534.

Petit, C., Campy, M., Chaline, J. \& Bonvalot, J. 1996: Major palaeohydrographic changes in Alpine foreland during the Pliocene-Pleistocene. Boreas $25,131-143$.

Pfiffner, O.A., Erard, P. \& Stäuble, M. 1997: Two cross sections through the Swiss Molasse Basin (lines E4-E6, W1, W7-W10). In: Pfiffner, O.A., Lehner, P., Heitzmann, P., Mueller, S. \& Steck, A. (Eds): Deep structure of the Swiss Alps. Results of NRP 20. Birkhäuser, pp. 64-72.

Philippe, Y. 1994: Transfer Zone in the Southern Jura Thrust Belt (Eastern France): Geometry, Development and Comparison with Analogue Modeling Experiments. In: Mascle, A. (Ed.): Hydrocarbon and Petroleum Geology of France, Volume 4: Special Publication of the European Association of Petroleum Geologists, A. Springer, 327-346.

Philippe, Y., Colletta, B., Deville, E. \& Mascle, A. 1996: The Jura fold-andthrust belt: a kinematic model based on map-balancing. In: Ziegler, P. \& Horvath, F. (Eds.): Peri-Tethys Memoir 2: Structure and prospects of Alpine Basins and Forelands, Volume 170: Paris, Mémoires du Muséum National d'Histoire Naturelle 235-261.

Plenefisch, T. \& Bonjer, K. 1997: The stress field in the Rhine Graben area inferred from earthquake focal mechanisms and estimation of frictional parameters. Tectonophysics $275,71-97$.

Reinecker, J., Heidbach, O. \& Mueller, B. 2003: The 2003 release of the World Stress Map (available online at www.world-stress-map.org).

Rénass 2004: Réseau National de Surveillance Sismique, Ecole et Observatoire des Sciences de la Terre de Strasbourg, http://renass.u-strasbg.fr/, accessed on 04-04-2004.

Ruhland, M., Blanalt, J.G. \& Bômont, M. 1973: Carte Géologique detaillée de la France à $1 / 50$ 000, Ferrette, feuille XXXVII-22. Ministère du développement industriel et scientifique, Bureau de recherches géologiques et minières, Service Géologique National, Orléans.
Sommaruga, A. 1997: Geology of the Central Jura and the Molasse Basin: New insights into an evaporite-based foreland fold and thrust belt. $\mathrm{PhD}$ Thesis, Université de Neuchâtel, Mémoires de la Société Neuchâteloise des Sciences Naturelles 12, Neuchâtel, 176 pp.

Schmidt, C., Braun, L., Paltzer, G., Mühlberg, M., Christ, P. \& Jacob, F. 1924: Bohrungen von Buix bei Pruntrut und Allschwil bei Basel. Beiträge zur Geologie der Schweiz. Geotechnische Serie, X. Lieferung, 74.

Schneegans, D. \& Théobald, N. 1948: Observations nouvelles sur le Chevauchement frontal du Jura Alsacien. Bulletin de la Société géologique de France 18, 89-95.

Schumacher, M.E. 2002: Upper Rhine Graben: Role of preexisting structures during rift evolution. Tectonics 21: 1006, doi:10.1029/2001TC900022.

Sprecher, C. \& Müller W. 1986: Geophysikalisches Untersuchungsprogramm Nordschweiz: Reflexionsseismik 82. NAGRA Technischer Bericht 84-15, NAGRA, Baden, 168 pp.

Swiss Seismological Service, ETH Zürich 2003: ECOS - Earthquake Catalog of Switzerland, http://seismo.ethz.ch/.

Swiss Seismological Service, ETH Zürich 2004: Regional Moment Tensor Catalog, http://www.seismo.ethz.ch/moment_tensor/2004/homepage.html.

Tesauro, M., Hollenstein, C., Egli, R., Geiger, A. \& Kahle, H.-G. 2005: Continuous GPS and broad-scale deformation across the Rhine Graben and the Alps. International Journal of Earth Sciences 94, 525-537, doi: 10.1007/s00531-004-0453-0.

Théobald, N. 1934: Les alluvions du Pliocène supérieur de la région du Sundgau. Bulletin de la Société Industrielle de Mulhouse 101,1-36.

Théobald, N., Dubois, G. \& Goguel, J. 1958: Carte Géologique de la France à 1/50 000, feuille Altkirch-Huningue + notice explicative, XXXVII-21, Service de la Carte Géologique de la France, Paris.

Théobald, N., Vogt, H. \& Wittmann, O., 1977: Néotectonique de la partie méridionale du bloc rhénan. Bulletin du Bureau de recherches géologiques et minières (deuxième série), v. IV, 121-140.

Ustaszewski, K., Schumacher, M.E., Schmid, S.M. \& Nieuwland, D. 2005a: Fault reactivation in brittle-viscous wrench systems - dynamically scaled analogue models and application to the Rhine-Bresse Transfer Zone. Quaternary Science Reviews 24, 363-380, doi:10.1016/j.quascirev. 2004.03.015.

Ustaszewski, K., Schumacher, M.E. \& Schmid, S.M. 2005b: Simultaneous normal faulting and extensional flexuring during rifting: an example from the southernmost Upper Rhine Graben. International Journal of Earth Sciences 94, 680-696, doi: 10.1007/s00531-004-0454-z.

Ustaszewski, K. \& Schmid, S.M. 2006: Control of pre-existing faults on geometry and kinematics in the northernmost part of the Jura fold and thrust belt. Tectonics 25, TC 5003, doi 10.1029/2005TC001915.

Wells, D.L. \& Coppersmith, K.J. 1994: New empirical relationship among magnitude, rupture length, rupture width, rupture area, and surface displacement. Bulletin of the Seismological Society of America 84, 974-1002.

Ziegler, P.A. 1990: Collision related intra-plate compression deformations in Western and Central Europe. Journal of Geodynamics 11, 357-388.

Ziegler, P.A. 1992: European Cenozoic rift system. Tectonophysics 208, 91-111.

Ziegler, P.A., Schumacher, M.E., Dèzes, P., Van Wees, J.-D. \& Cloetingh, S. 2004: Post-Variscan evolution of the lithosphere in the Rhine Graben area: constraints from subsidence modelling. In:Wilson, M. (Ed.): PermoCarboniferous magmatism and rifting in Europe, Volume 223: Geological Society of London Special Publications, Geological Society, 289-317.

Manuscript received November 4, 2006

Manuscript accepted February 5, 2007 